\title{
The importance of geological conditions for the formation of past thermokarst closed depressions in the loess areas of eastern Poland
}

\author{
Renata KOŁODYŃSKA-GAWRYSIAK ${ }^{1, *}$, Marian HARASIMIUK ${ }^{1}$, Łukasz CHABUDZIŃSKI ${ }^{1}$ \\ and Waldemar JEZIERSKI ${ }^{1}$
}

1 Maria Curie-Skłodowska University, Faculty of Earth Science and Spatial Management, al. Kraśnicka 2 CD, 20-718 Lublin

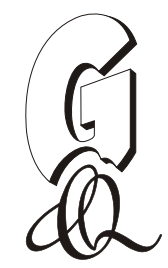

\begin{abstract}
Kołodyńska-Gawrysiak, R., Harasimiuk, M., Chabudziński, Ł., Jezierski, W., 2018. The importance of geological conditions for the formation of past thermokarst closed depressions in the loess areas of eastern Poland. Geological Quarterly, 62 (3): 685-704, doi: 10.7306/gq.1431
\end{abstract}

\begin{abstract}
Closed depressions (CDs) are common forms occurring in the European loess belt. So far, investigations of CDs in Europe have suggested various natural or/and anthropogenic processes leading to their formation. The origins of CDs occurring in the loess areas of Poland have been the subject of few investigations, and their results have not clarified the problem. Most frequently, the age of CDs is linked with the post-glacial period, or the final stages of the formation of the loess cover. The investigations of CDs carried out in eastern Poland (Nałęczów Plateau) have so far revealed some patterns with regard to the morphometric characteristics and distribution of CDs on the regional scale. They also suggest the impact of thermokarst processes on the formation of the CDs. Five main lithogenetic types of sediment underlying the loess cover have been documented: glacial tills, clay and clayey loams, patches of glacial tills and sandy deposits, sands with gravels, and the bedrock. The relief under the loess cover has also been documented. The types of sediment as well as the relief under the loess cover have an impact on local differences of water content in the loess sediments. It was found that the variatiability of the geological conditions in the Nałeczów Plateau in the Pleistocene had an impact on the local variation of the ice content in the upper part of the former permafrost. This led to local predispositions for the development of thermokarst CDs during the Last Glacial. Areas with a high density of CDs have less permeable sediments (glacial tills, clay and clayey loams) and small relative heights under the loess cover. In the Pleistocene, these areas had higher ice content in the upper part of the permafrost. A model of thermokarst CDs development in the loess areas in eastern Poland is proposed. The model shows that the distribution and size of thermokarst CDs depends on the thickness of the loess cover as well as the types and relief of sediments underlying the loess. The development of thermokarst in the region studied may have consisted of multiple stages resulting in superimposed CDs. Between two and four stages of thermokarst CDs development can be distinguished on the Nałeeczów Plateau. The two main stages occurred in MIS 4/3 ( 58 ka or 55-50 ka Oerel and Glinde interstadials) and MIS 2/1 ( 12 ka). These landforms may have developed also during the Denekamp Interstadial (32-28 ka) and $\sim 15 \mathrm{ka}$. The present investigations indicate significant morphogenetic effects of permafrost melting on the contemporary relief of the loess areas.
\end{abstract}

Key words: closed depressions, loess, past permafrost, thermokarst, geological conditions.

\section{INTRODUCTION}

Thermokarst is a process whereby characteristic landforms result from the thawing of ice-rich permafrost or the melting of massive ice. Thermokarst as a topographic depression may develop subsequently to a disturbance of the surface thermal regime in areas of ice-rich permafrost (Czudek and Demek, 1970; Harry and French, 1983; French, 2007; Toniolo et al., 2009).

In the post-glacial period, thermokarst relief has developed due to the thawing of ice-rich permafrost in Central Yakutia, Canada and Alaska (Czudek and Demek, 1970; Morgenstern et al., 2013). In the present and past permafrost zone,

\footnotetext{
* Corresponding author, e-mail: renata.kolodynska-gawrysiak@poczta.umcs.lublin.pl
}

Received: January 17, 2018; accepted: May 26, 2018; first published online: October 9, 2018 thermokarst depressions are commonly found (Black, 1969; Goździk, 1995; Murton et al., 2015). The number and distribution of thaw depressions in northern Alaska and northwestern Canada seem to reflect the variation of ice content in permafrost depending on the lithological features of the sedimentary deposits (Black, 1969; Farquharson et al., 2016). Late Glacial thermokarst depressions were also inferred by De Groot et al. (1987) in the north of the Netherlands and by Sparks et al. (1972) in England.

In Poland, the thawing of the ice infilling the Pleistocene polygonal crack networks led to the formation of closed depressions documented in the moraine plains of the Wielkopolska region (Stankowski, 2012). The occurrence of various generations of Pleistocene polygonal crack networks in this area has been documented by Ewartowski et al. (2016).

Closed depressions (CDs) are common forms occurring in the European loess belt. The thermokarst origins of CDs in the European loess belt have been suggested by many authors (see references in Kołodyńska-Gawrysiak and Poesen, 2017). The study region is located around $51^{\circ} \mathrm{N}$, within the maximum 
extent of Last Glacial continuous permafrost (Vandenberghe et al., 2014). CDs in the east of Poland (Nałęczów Plateau) are small landforms on the surface of the loess cover that was accumulating until 15,000-12,000 BP (Maruszczak, 1976, 1980). The distribution of CDs in the Nałęczów Plateau is uneven, which results from local geological determinants impacting the formation of CDs (Kołodyńska-Gawrysiak et al., 2015). The main research objective is to assess the impact of the geological conditions on the Nałęczów Plateau on the possible formation of thermokarst CDs during the Last Glacial.

Investigating the origins of CDs is important for understanding the main processes influencing the morphogenesis of the loess cover in the post-glacial period. It will also enable an assessment of the morphogenetic effects of permafrost melting on the contemporary relief of the loess areas. More research is needed to unravel the origins and evolution of these depressions to better understand the importance of the Last Glacial stages for the morphogenesis and geodiversity of the loess belt in Europe.

\section{GEOLOGICAL SETTING}

LITHOSTRATIGRAPHY AND MORPHOLOGY OF THE LOESS COVER ON THE NAŁĘCZÓW PLATEAU

The loess cover of the Nałęczów Plateau consists of several loess patches of varying size, separated by river valleys where the loess cover is absent. The thickness of the loess cover varies both on the regional scale and within the individual patches. It reaches its maximum values in the western part and along the northern boundary of the region (up to $30 \mathrm{~m}$ ). In the eastern part of the Nałęczów Plateau, the loess cover is usually 10 to 20 m thick (Harasimiuk, 1987). The loess cover conceals small forms of the underlying deposits and mirrors the basic elements of their relief (Harasimiuk and Henkiel, 1976).

According to Maruszczak's (1991) stratigraphic scheme, the loess cover on the Nałęczów Plateau mainly consists of younger loess (LM) that accumulated during the Vistulian Glaciation from ca. $50,000 \mathrm{BP}$ to $15,000 / 12,000 \mathrm{BP}$ as well as, locally, of older upper loess $(\mathrm{LSg})$ that accumulated during the Wartanian Glaciation (Saale 2; 150,000 BP).

The older upper loess was documented only in the western part of the region. It is not very thick $(1.3 \mathrm{~m}$ in the Skowieszyn profile), and is characterized by complete decalcification, an increased mean grain size towards the top (Mz from 5.94 to $5.05)$, and poor sorting. LS and, in the eastern part of the region, the Saale glacigenic deposits, are overlain by the Eemian interglacial palaeosol, a well-developed forest soil with a thickness of $\sim 1.5 \mathrm{~m}$. It is a fossil soil with a typical sequence of soil horizons: humus horizon (A), luvic horizon (E) and argillic horizon (Bt) (Harasimiuk and Jezierski, 2001).

According to Harasimiuk (1987), LM accumulated in conditions of short-distance transport and winds from various directions and constitutes the greatest proportion of the region's loess cover. In the western part of the region (the Skowieszyn profile), the younger loess consists of four layers: LMn, LMd, LMs, LMg and initial soil horizons that developed on them (Harasimiuk and Jezierski, 2001). In the Vistulian loess (LM) 3-4 initial fossil soil horizons occur most frequently. The LMn layer has not been found in the eastern part of the region (the Dys profile).

The average grain size and sorting indices for the loess of the main LM succession increase from the bottom layers to the top. Carbonate content also increases in this direction (to $5 \%$ ).
The lower layers of LM are characterized by a smaller grain size (LMn and LMd: 0,021 mm, LMs: $0.016 \mathrm{~mm}$ ) than LMg $(0.023 \mathrm{~mm})$. The interstadial soil horizons show a decrease in carbonate content $(0.5-0.9 \%)$ and a small increase (by $~ 5 \%$ ) of the clay fraction content. The total thickness of the LMn, LMd and LMs layers in the region described does not exceed $10 \mathrm{~m}$. The upper younger loess $(\mathrm{LMg})$ is the thickest (up to a dozen metres thick; Harasimiuk and Jezierski, 2001). The clay fraction content decreases towards the top from 33 to $22 \%$. Sorting also increases towards the top. Carbonate content ranges between 4 and $9 \%$.

The western part of the Nałęczów Plateau is strongly dissected by old polygenetic erosion-denudation valleys incised into the bedrock (Gardziel et al., 2006; Gawrysiak and Harasimiuk, 2012). Holocene gully systems are inserted into these valleys, the average density of the gully network being $2.48 \mathrm{~km} / \mathrm{km}^{2}$, and the maximum density exceeding $10 \mathrm{~km} / \mathrm{km}^{2}$ (Gawrysiak and Harasimiuk, 2012). As a result of the strong dissection of this area, the loess plateaus constitute fairly narrow inter-valley hummocks (Fig. 1). The relative altitudes in the area exceed $40 \mathrm{~m}$ and reach $90 \mathrm{~m}$ in the vicinity of the Vistula River. The valley slopes are moderately steep, at $15-20^{\circ}$. CDs are rare in the western part of the Nałęczów Plateau (Fig. 1).

The eastern part of the Nałęczów Plateau is dissected by valley and gully systems to a lesser extent than the western part (Fig. 1). The mean gully density is $0.19 \mathrm{~km} / \mathrm{km}^{2}$ and the maximum density does not exceed $2 \mathrm{~km} / \mathrm{km}^{2}$ (Gawrysiak and Harasimiuk, 2012). The relative heights in the region reach $40-50 \mathrm{~m}$ and the slope inclination ranges from 8 to $12^{\circ}$. Extensive surfaces of an undulating loess plateau with numerous CDs are the predominant element of the landscape (Fig. 1).

\section{GEOLOGICAL STRUCTURE UNDER THE LOESS COVER} ON THE NAŁĘCZÓW PLATEAU

The bedrock of the Nałęczów Plateau consists of lithologically diverse, highly fractured Upper Maastrichtian and Paleogene calcareous rocks (Pożaryska, 1967; Harasimiuk, 1980). These include opokas, marly opokas, marl (Upper Maastrichtian) as well as Paleocene limestone, siltstone and carbonate sandstone (Harasimiuk and Henkiel, 1976). The bedrock is dissected by a network of tectonic gashes enabling the draining of water. The region's valley system is oriented according to the major fault direction (Harasimiuk, 1980; Henkiel and Nitychoruk, 1980). In the western part of the Nałęczów Plateau, the immediate vicinity of the Vistula valley functions as the base level of erosion and dissection by deep river valleys such as those of the Grodarz and Bystra rivers and their numerous tributary valleys that recently became partially dry. This area is extremely well-drained, as shown by the scarcity of surface waters. The elevation differences of the top of the Cretaceous-Paleocene succession exceed $150 \mathrm{~m}$ in this area. The degree of dissection decreases towards the east and does not exceed 70 m near Nałęczów (Harasimiuk and Henkiel, 1976, 1978). Groundwater in the Upper Cretaceous-Paleocene rocks is stored in fissure aquifers, and the zones of cracks and fissures have a decisive significance for underground circulation (Michalczyk, 1986).

The bedrock underlies a bipartite Pleistocene sedimentary succession characterized by high local lithological variation and varying thickness. The lower part of this succession is made up of glacial deposits (glacial tills), glaciofluvial deposits (sands and gravels) and limnoglacial deposits (clayey loams, clay), of different ages. The upper part is made up of loess (Harasimiuk and Henkiel, 1978; Pożaryski et al., 1994). 


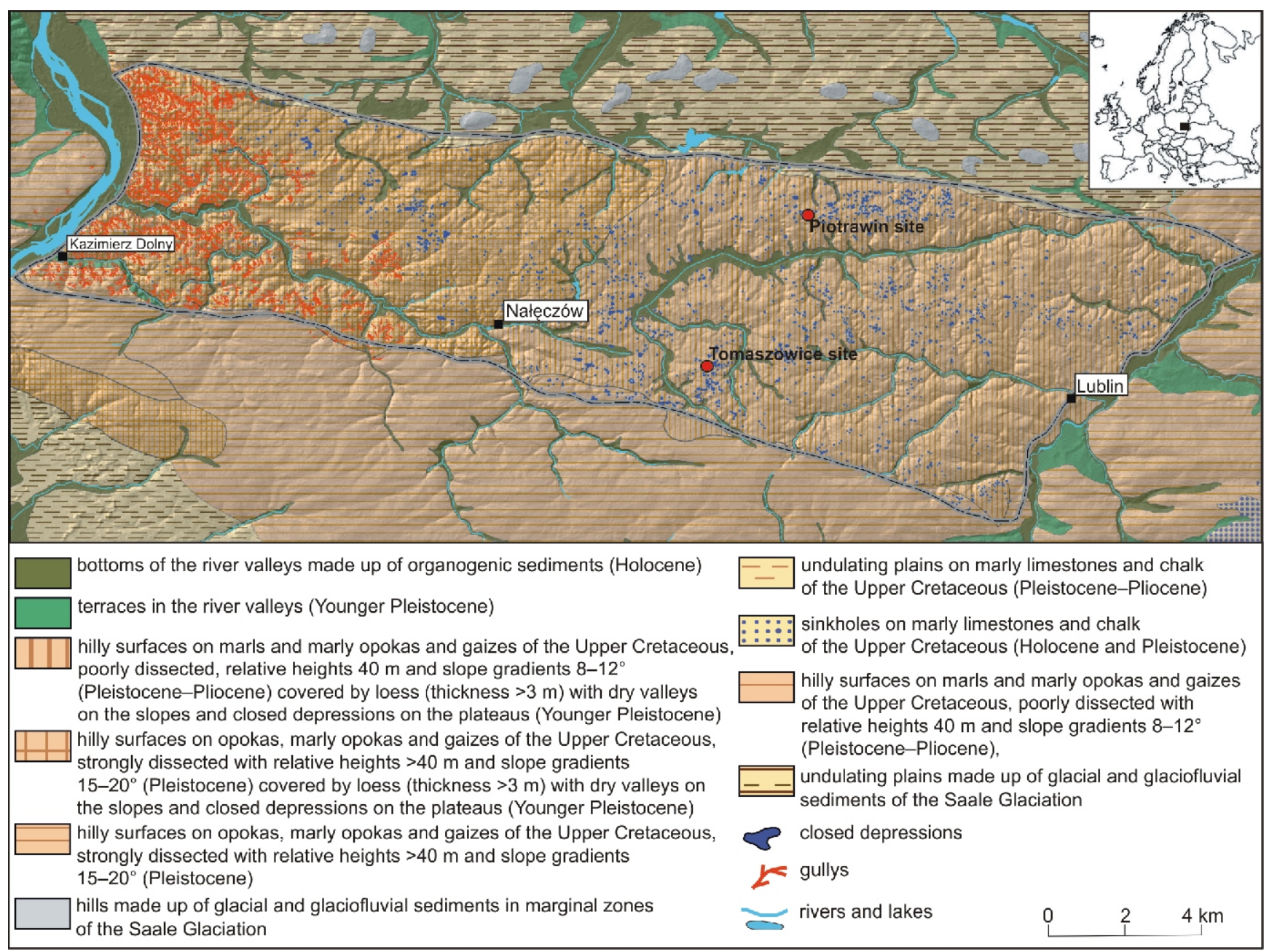

Fig. 1. Geomorphological map of the Nałęczów Plateau (after Maruszczak, 1964)

Red dots mark the CDs studied

Two layers of glacial till have been documented on the Nałęczów Plateau: one from the Odranian (Saale 1), the other from the Sanian (Elsterian) Glaciation. Glacial tills of the Odranian (Saale 1) Glaciation form a thick deposit at the bottom of the loess. Glacial tills of the Sanian (Elsterian) Glaciation occur at the bottom of the Quaternary succession. Locally, the two till horizons overlap, forming thick clayey successions reaching a thickness of $35 \mathrm{~m}$. The relief of the sedimentary deposits underlying the loess cover has a significant impact on the hydrogeological conditions. This was formed during the Odranian Glaciation over the greater part of the Nałęczów Plateau. In the opinion of Harasimiuk and Henkiel (1978), the accumulation relief after the recession of the Odranian (Saale 1) Glaciation was characterized by hills made up of moraine tills and flat, wide depressions (probably dead-ice depressions) frequently filled with limnoglacial, clayey deposits. These forms, along with kame hills, were features of the highly diverse relief of the marginal zone of the Odranian (Saale 1) Glaciation. North of the Ciemięga and Bystra valleys, there is a zone of head moraine hills made up of glacial tills with an average thickness $>15 \mathrm{~m}$. South of the Bystra valley, there are undulating kames mostly built of sandy and clayey deposits (Harasimiuk and Henkiel, 1976). Glacial tills usually form a thin and discontinuous cover south of the Bystra valley. Numerous thin covers of sandur type occur in the western part of the Nałęczów Plateau
(Harasimiuk and Henkiel, 1978). They are formed of glaciofluvial deposits from the Odranian (Saale 1) Glaciation, represented by sands with gravels. In the eastern part of the region, glacial tills interbedded with glaciofluvial deposits form a thick succession (>25 m; Harasimiuk and Henkiel, 1981).

Locally, on the regional scale, a layer of carbonate-bearing clayey loams or clays, the thickness of which ranges from several to ten or so metres, overlie glacial tills from the Odranian (Saale 1) Glaciation or, directly, the bedrock. The geological context suggests that these are ice-marginal lake (limnoglacial) deposits from the Odranian (Saale 1) Glaciation. Clayey loams were found to occur at the bottom of the loess cover extensively in the vicinity of Pożóg, Klementowice and Karmanowice as well as around Sadurki, Ożarów, Miłocin and Tomaszowice. Data obtained in water well surveys indicate that these deposits are highly saturated with water, and they form a quicksand horizon (Harasimiuk and Henkiel, 1978).

In the Quaternary deposits on the plateau tops, groundwater occurs locally in perched aquifers at the depth of several to ten or so metres, at the bottom of the loess layer. This water remains beneath poorly permeable layers, mainly glacial tills or ice-marginal lake loams (Michalczyk, 1986; Nowacka, 1992). The relief of the impermeable deposits underlying the loess cover determines the hydraulic gradients and possibility of water flow. 
METHODS

The research is based on data from archive geological boreholes, obtained from the HYDRO Bank of the Polish Hydrogeological Survey, geological boreholes and profile data prepared for the published and unpublished sheets of the Detailed Geological Map of Poland, scale 1:50,000, sheets: Lublin, Kazimierz Dolny, Kurów and Nałęczów, as well as data from the authors' own geological boreholes. Altogether geological data from 346 boreholes were used.

From the entire spectrum of data contained in the geological and hydrogeological documentation, information was selected concerning the location of the boreholes as well as the borehole/depth characteristics and lithostratigraphic characteristics of the profiles. The borehole descriptions were analysed in detail in order to carry out a lithogenetic interpretation of the deposits recorded in the individual geological profiles. Five main lithogenetic types of deposit were distinguished: loess, glacial tills, sands with gravels, clay and clayey loams and the bedrock. In the second stage, spreadsheet data were converted in the spatial data format into an .shp file. The file was generated in the PUWG92 system and it contained information on the spatial location of the CDs, the geological formations and depths at which they occur. The types and the depth at which the individual types of deposit occur were interpolated. On that basis, the following maps were prepared: lithological types of deposit under the loess cover, relative heights of deposits underlying the loess cover (the relief under loess cover). The interpolation was carried out using ArcGIS 10.0 software and the Topo to Raster tool.

Two representative CDs were chosen for detailed investigation. They are located in areas with a large number of closed depressions but with a different geological structure. About 30 soil-auger holes were bored and two trenches $(2 \mathrm{~m}$ long, $1 \mathrm{~m}$ wide, $2 \mathrm{~m}$ deep) were dug in each of the selected CDs. The trenches were located in the deepest point and on the slopes of each CD. The soil-auger holes were located in two transects, intersecting at a right angle, across each CD. All soil-auger holes and trenches were documented and described according to standard methods. In the bottoms of two representative CDs two $15 \mathrm{~m}$ deep boreholes using a mechanical boring rig were made. The morphological properties of the sedimentary layers and soil horizons were also documented and described according to Guidelines for Soil Descriptions (2006).

The dating of the soil horizons and sediment layers was carried out using the radiocarbon and OSL methods. Samples for dating were collected directly from the exposures in the trench wall from fossil soils and deposits infilling the CDs. Soil matrix samples and charcoals were taken from the buried humus horizons for C-14 dating. The radiocarbon dating of soil samples (humin acids) was carried out at the Poznań Radiocarbon Laboratory and Gliwice Radiocarbon Laboratory, Poland. The OSL analysis was performed at the OSL Laboratory in Lublin.

Electrical resistivity profiles were made in two representative CDs in order to examine the relief on the sedimentary units underlying the loess cover. Deep boreholes with a mechanical soil probe were conducted in the bottoms of the CDs in order to determine the depth of loess decalcification underneath the bottoms of the CDs.

\section{RESULTS}

\section{GEOLOGICAL STRUCTURE OF THE CLOSED DEPRESSIONS}

Tomaszowice site. The closed depression at Tomaszowice developed within an 8-10 m thick loess cover overlying carbonate clayey loams (Fig. 2A). Analysis of the electrical resistivity profiles shows that the clayey loams lie almost horizontally (Fig. 2A). No depression below the current form was found under the loess cover. The CD at Tomaszowice is covered by a polygenetic Late Vistulian-Holocene soil that developed in situ on loess (Fig. 2B). Well-developed, intact soil profiles were documented across the entire area of the $C D$. The soil structure is A-E-Bt1-Bt2-Bt/C-C. The eluvial horizon $(E)$ at the bottom of the $C D$ is particularly deep here (i.e. $70 \mathrm{~cm}$ ) as a result of the slow accumulation of colluvial deposits beneath a forest. The deposits making up the bottom of horizon $E$ (depth of $70 \mathrm{~cm}$ ) were dated at $13.1 \pm 0.8 \mathrm{ka}$ (Appendix $1^{*}$ and Fig. 2B). In accordance with the stratigraphy, the ages of the deposits were $7.29 \pm 0.42 \mathrm{ka}$ (at $50 \mathrm{~cm}$ depth), $5.49 \pm 0.34 \mathrm{ka}$ (at $40 \mathrm{~cm}$ depth) and $3.70 \pm 0.24 \mathrm{ka}$ (at $25 \mathrm{~cm}$ depth) respectively (Appendix 1). In profiles located on the slopes of the $C D$, the calcareous loess horizon was found at the depth of $170-210 \mathrm{~cm}$ (Fig. 2B). The lower boundary of the calcareous loess reflects the current topography and descends steeply below the footslopes of the CD. In the bottom of the CD, calcareous loess was not found in soil-auger holes bored through the whole loess cover (8 m; Fig. 2B)

Piotrawin site. The closed depression at Piotrawin developed within a 10-14 m thick loess cover (Fig. 3A). The loess is underlain by glacial till, the top of which is varied. The electrical resistivity profile suggests the existence of a shallow depression on the surface of the glacial till below the depression developed in the loess (Fig. 3A). The original surface of the bottom of CD is covered by a Late Vistulian-Holocene fossil soil Ab-Bht-Bt1$\mathrm{Bt} 2-\mathrm{Bt} / \mathrm{C}-\mathrm{C}$ that developed on loess in situ (Fig. 3B). The age of humic acids from horizon Bht $(10130 \pm 60 \mathrm{cal} B P)$ and horizon $\mathrm{Ab}(645 \pm 30 \mathrm{cal} \mathrm{BP})$ of this soil and its stratigraphic position indicate that the soil developed from the Late Vistulian until the Middle Atlantic Period (Table 1 and Fig. 3B). Calcareous loess was found on the slopes of the CD, at a depth of 110-300 cm (Fig. 3B). The top of the calcareous loess layer runs parallel to the current topography and descends rapidly below the lower sections of the CD slopes. At the bottom of the CD, calcareous loess was not found in the auger hole bored through the entire loess cover (14 m; Fig. 3B). The CD in Piotrawin is filled with $100 \mathrm{~cm}$ of Holocene colluvial deposits (Fig. 3B).

The geological structure of the CDs studied as well as results of datting suggest that CDs have developed in the loess in situ and subsequently the primary floors of the CDs were covered by Late Glacial-Holocene fossil soils. During the Holocene, the CDs were infilled by colluvial sediments related to human impact and climate change. 


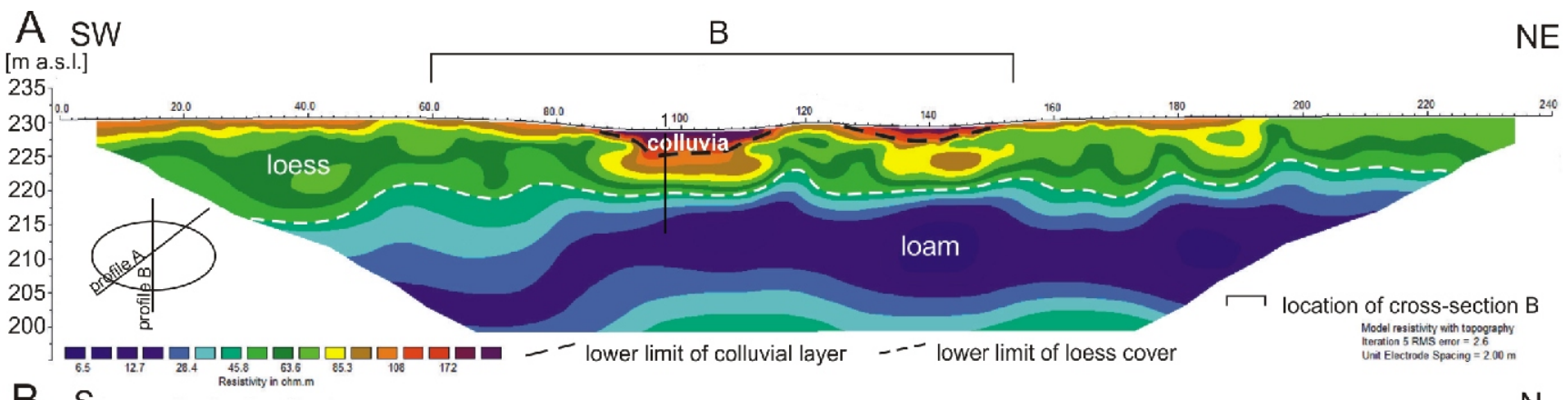

B S

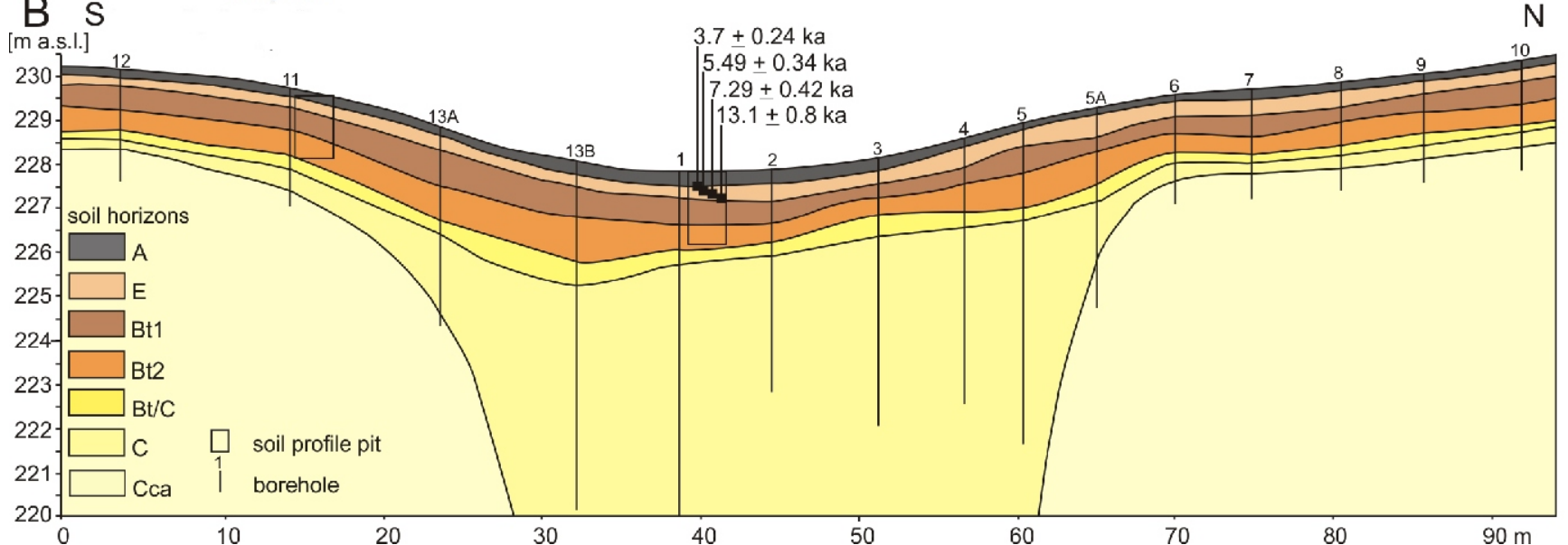

Fig. 2. Electrical resistivity profile (A) and cross-section (B) of the $C D$ at the Tomaszowice site

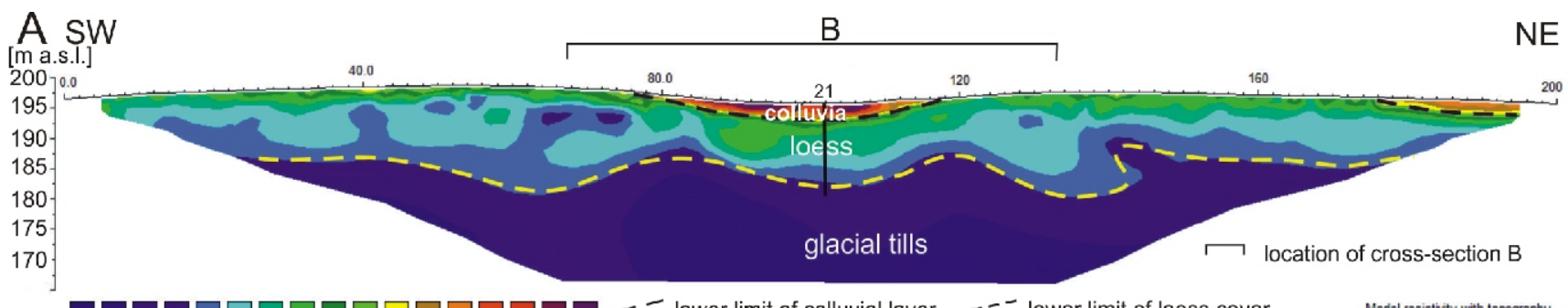

${ }_{28.4}{ }_{40.2} \square_{56.8} \square \square_{80.3} \square \square_{113} \square \square_{160} \square \square_{226} \square \square_{320} \square \square-$ lower limit of colluvial layer $\quad$ - - lower limit of loess cover

B SW

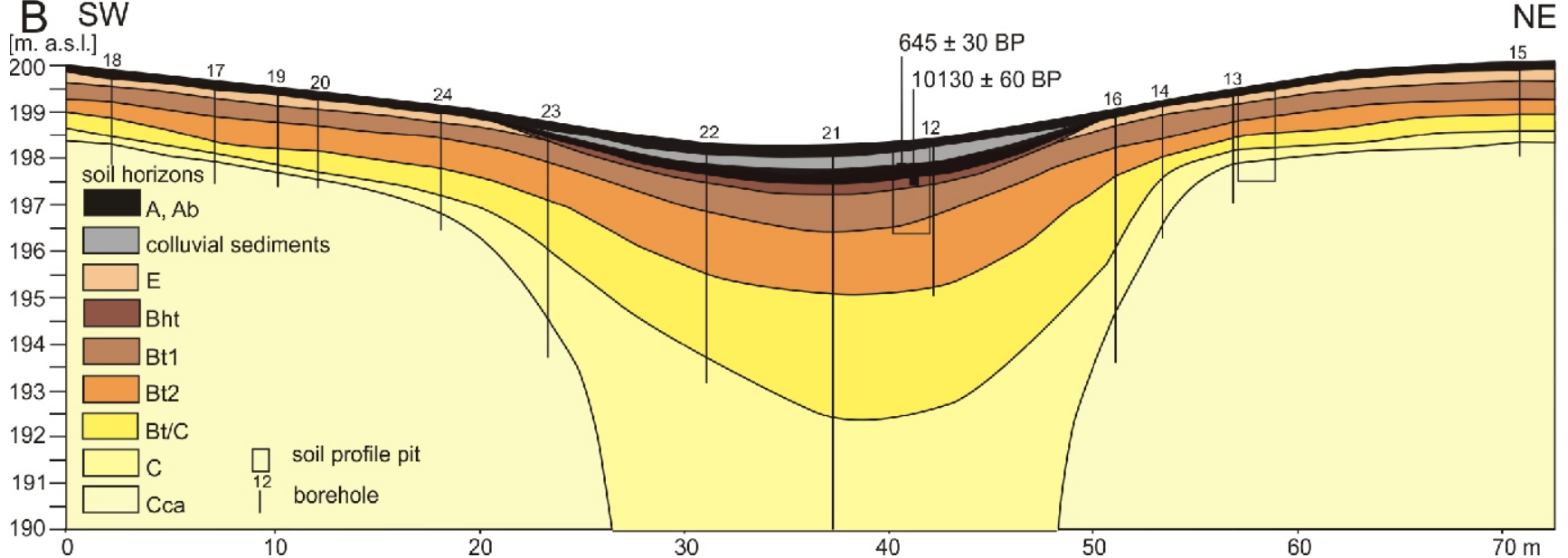

Fig. 3. Electrical resistivity profile (A) and cross-section (B) of the CD at the Piotrawin site 
Results of C-14 dating of the CDs studied

\begin{tabular}{|c|c|c|c|c|c|}
\hline Laboratory code & Profile & Depth [m] & Material & Age BP & Calibrated age (OxCal 4.2; 95.4\%) \\
\hline GdA-2955 & \multirow{2}{*}{ Jastków } & 0.8 & charcoal & $840 \pm 25$ & 1161-1257 AD \\
\hline GdS-1446 & & 1.3 & humus & $6550 \pm 110$ & $5671-5310 \mathrm{BC}$ \\
\hline Poz-73769 & \multirow{2}{*}{ Piotrawin } & 0.8 & humus & $645 \pm 30$ & $1281-1396$ AD \\
\hline Poz-73770 & & 1.5 & humus & $10130 \pm 60$ & 10078-9456 BC \\
\hline
\end{tabular}

THE DISTRIBUTION OF CLOSED DEPRESSIONS IN RELATION TO THE GEOLOGICAL CONDITIONS UNDER THE LOESS COVER

Closed deoressions microregions in the Nałęczów Plateau were distinguished as areas with high concentrations of closed depressions (Kołodyńska-Gawrysiak and Chabudziński, 2012). Large concentrations of CDs occur in areas where the loess cover is underlain by a thick succession of glacigenic deposits with a predominance of glacial tills or clayey loams (Fig. 4). This correlation is clear in the case of CDs microregions such as Kopanina-Drzewce, Nałęczów-Czesławice, Bogucin-Gutanów, Piotrawin-Smugi (Fig. 4). They are located in an area where the loess covers a zone of Odranian (Saale 1) glacial sediment accumulation the thickness of which exceeds $20 \mathrm{~m}$. The loess-covered ridge of the recessional moraine extends to the north of the Ciemiegga valley. In the western part of this zone, an area with clay and clayey loams deposits underlying the loess was found locally. It is accompanied by concentrations of CDs in the microregions of Klementowice-Zażuk and Karmanowice (Fig. 4). Areas with small relative heights of the substrate underlying the loess cover, of not more than $10 \mathrm{~m}$, predominate in the eastern part of the Odranian (Saale 1) marginal zone (Fig. 5). At the same time, the concentration of the CDs reaches the highest density here in the entire region (Piotrawin-Smugi microregion).

The detailed geological situation of the eastern part of the Odranian (Saale 1) recessional zone is shown in cross-section A-B (Fig. 6). The loess cover, of varying thickness, overlies a ridge composed of moraine tills. CDs are concentrated in the zone located where a thick glacial till succession lies almost horizontally under the loess (Fig. 6). Despite the maximum thickness of glacial till, relatively few CDs occur immediately over the zone of the buried moraine ridge, where the elevation differences of sedimentary units underlying the loess cover increase to $15 \mathrm{~m}$. The loess-covered Odranian (Saale 1) marginal zone continues in the western part of the region. In this zone, the relief of the sedimentary units underlying the loess cover is more varied, with relative heights locally reaching $25 \mathrm{~m}$. Two small areas (Zażuk, Kopanina) with a high concentration of $\mathrm{CDs}$, reaching $30 \mathrm{CDs} / \mathrm{km}^{2}$, occur there (Fig. 4).

On the Ciemięga-Czechówka interfluve (Płouszowice-Rudnik CDs microregion), the density of CDs locally reaches $30 \mathrm{CDs} / \mathrm{km}^{2}$ (Fig. 4). The detailed geological structure of this area is shown in profile C-D (Fig. 7). The loess here is underlain by a thick succession of glacigenic deposits from the Sanian (Elsterian) and Odranian (Saale 1) Glaciation, represented by glacial tills and sands with gravels. The distribution of these main lithologies shows spatial variation. Because of this, the loess is underlain by patches of glacial till or glaciofluvial sands with gravels (Fig. 7). The relief of the sedimentary units underlying the loess cover is also highly variable (Figs. 5 and 7). Locally, the layers of glacial till and sands with gravels have a greater inclination (northern and southern part of the cross-section C-D; Fig. 7). Locally, they lie subhorizontally or form con- cavities in the substrate (central part of cross-section). The zone with the highest density of CDs occurs in the central part of the loess plateau between the Ciemięga and Czechówka rivers (Fig. 4).

High concentrations of CDs also occur outside the zone of thick glacial deposits, e.g. the closed depressions microregions Sadurki-Miłocin and Miłocin Kolonia-Tomaszowice Kolonia, where their density reaches $40 \mathrm{CDs} / \mathrm{km}^{2}$ (Kołodyńska-Gawrysiak and Chabudziński, 2012; Fig. 4). These microregions are located in a zone where the loess is underlain by clayey loams 5 to $12 \mathrm{~m}$ thick which represent marginal lake sediments overlying or transitioning into glacigenic sediments (Figs. 8 and 9). Locally, clayey loams cover ridges composed of opoka or marl, forming kame mesas (Figs. 8 and 9). The relief of the top surface of the clayey deposits shows little variation. The largest areas are characterized by differences in the relative heights of the deposits underlying the loess cover of up to 5 or $10 \mathrm{~m}$. In exceptional cases, the differences may reach $15 \mathrm{~m}$ in the zone of kame slopes (Figs. 8 and 9).

Few CDs occur on the western part of the Nałęczów Plateau despite the presence there of glacigenic deposits (Fig. 4). The geological structure of the western part of the Nałęczów Plateau, north of the Bystra valley, is shown in cross-section I-J (Fig. 10). A thick succession of Pleistocene glacigenic deposits underlies the loess (Fig. 10). The main component of this succession are the thick bipartite sequences of glacial tills from the Elsterian and Saale glaciations. Sands with gravels and clay deposits occurring between the glacial till layers have a smaller share in the geological structure. The relief of the sedimentary units underlying the loess cover in the western part of the Nałęczów Plateau is more varied than along cross-section I-J that runs along the watershed. The relative heights, up to $90 \mathrm{~m}$, reach the maximum values here on the regional scale (Fig. 5). They result from the occurrence of a dense $\left(5 \mathrm{~km} / \mathrm{km}^{2}\right)$ network of dry valleys (Maruszczak, 1973). These valleys discharge into the valleys of the Vistula and the Bystra, and their age is pre-Pleistocene. The loess cover did not fill these valleys completely because it corresponds to their relief (Śnieszko, 1995).

Small concentrations of CDs occur in areas where the loess lies directly on the bedrock or with a thin and discontinuous layer (a few metres thick at most) of glacigenic or sandy deposits (Fig. 4). An example of this pattern is an area with a small number of depressions, located between the Bystrzyca and Potok Konopnicki rivers (Konopnica-Stasin microregion). In most of the area, the density of the CDs does not exceed $5 \mathrm{CDs} / \mathrm{km}^{2}$, although locally it can reach $20 \mathrm{CDs} / \mathrm{km}^{2}$.

CDs occur sporadically on the western part of the Nałęczów Plateau, south of the Bystra valley. Patches of sandy glaciofluvial deposits predominate beneath the loess cover. The relative heights under the loess cover reach $30 \mathrm{~m}$, mainly as a result of the strong dissection of this area by valley systems (Fig. 5). 


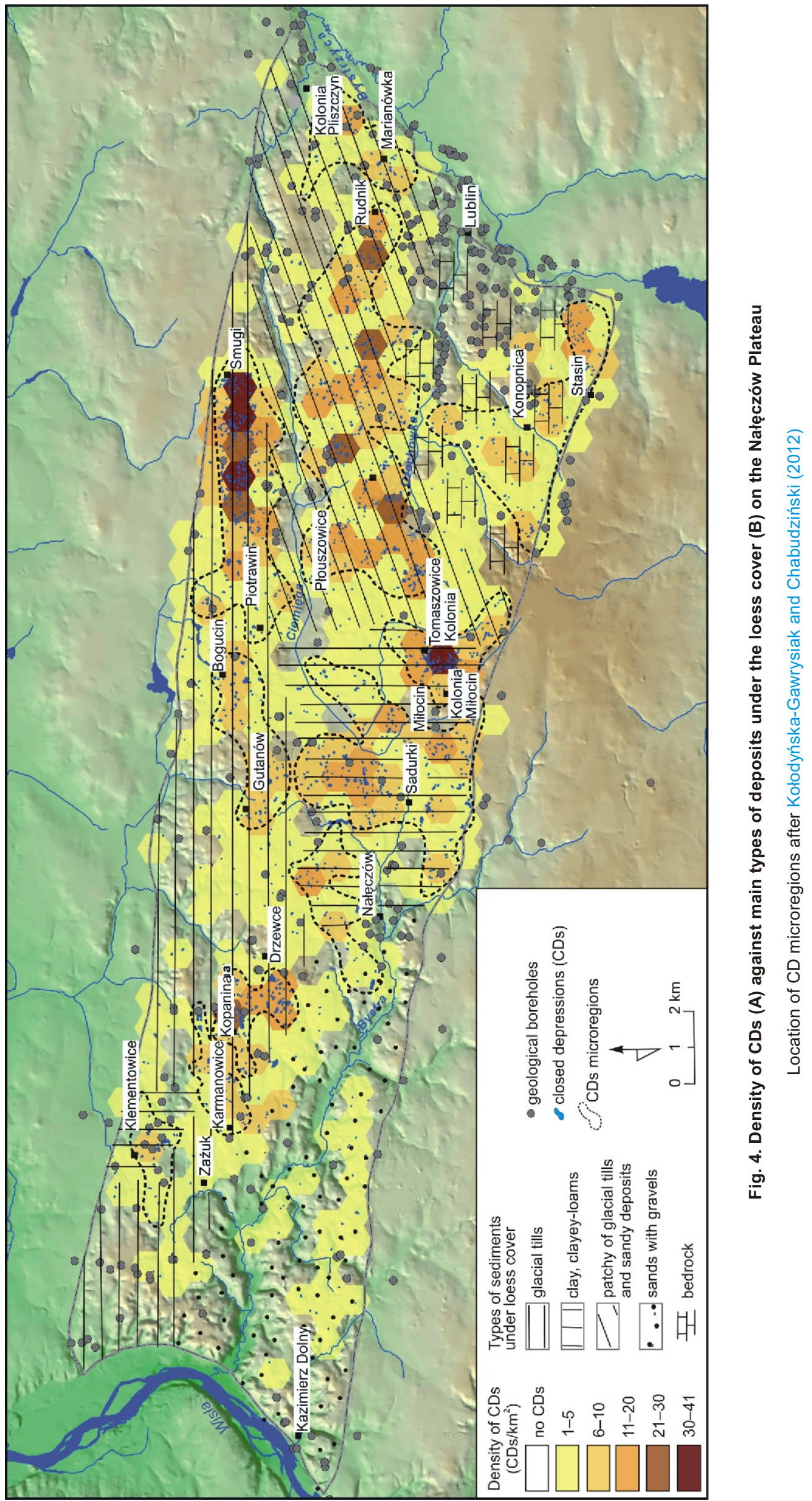




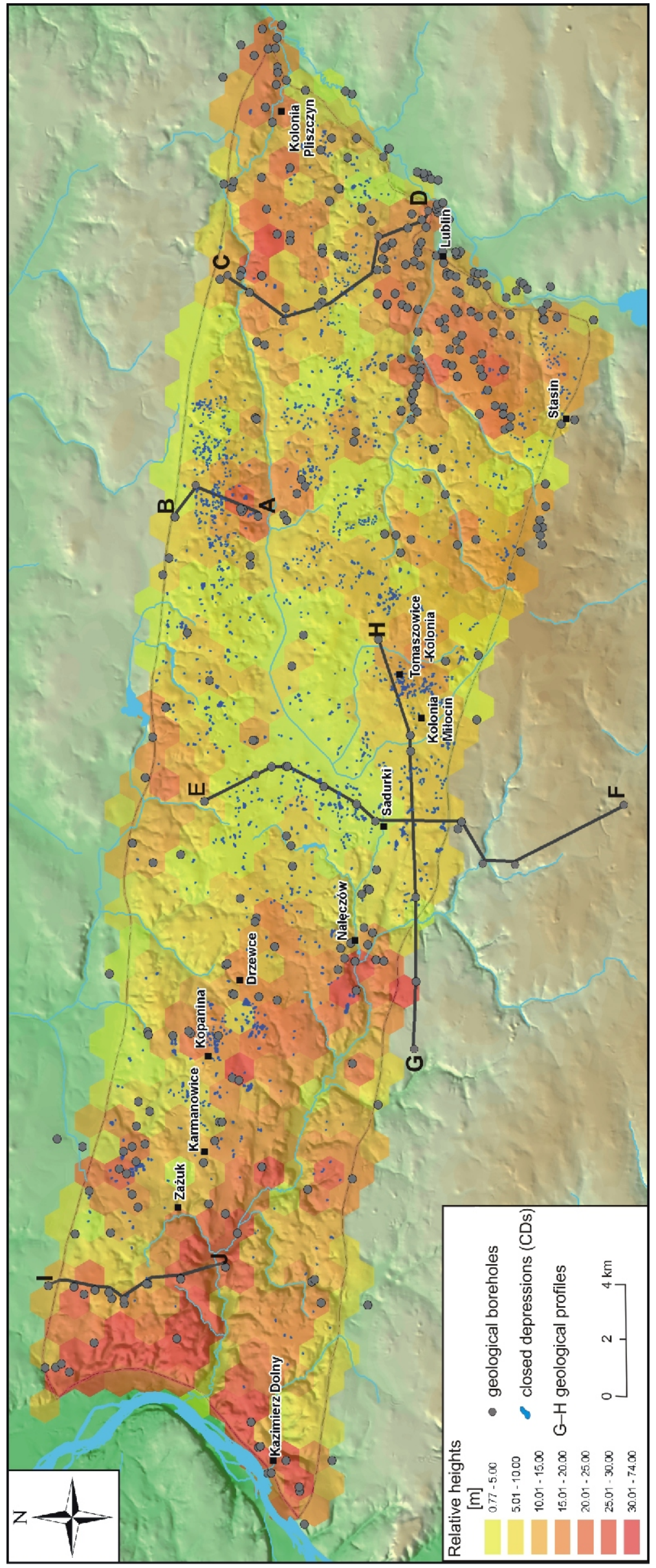

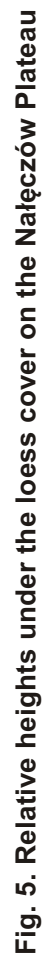




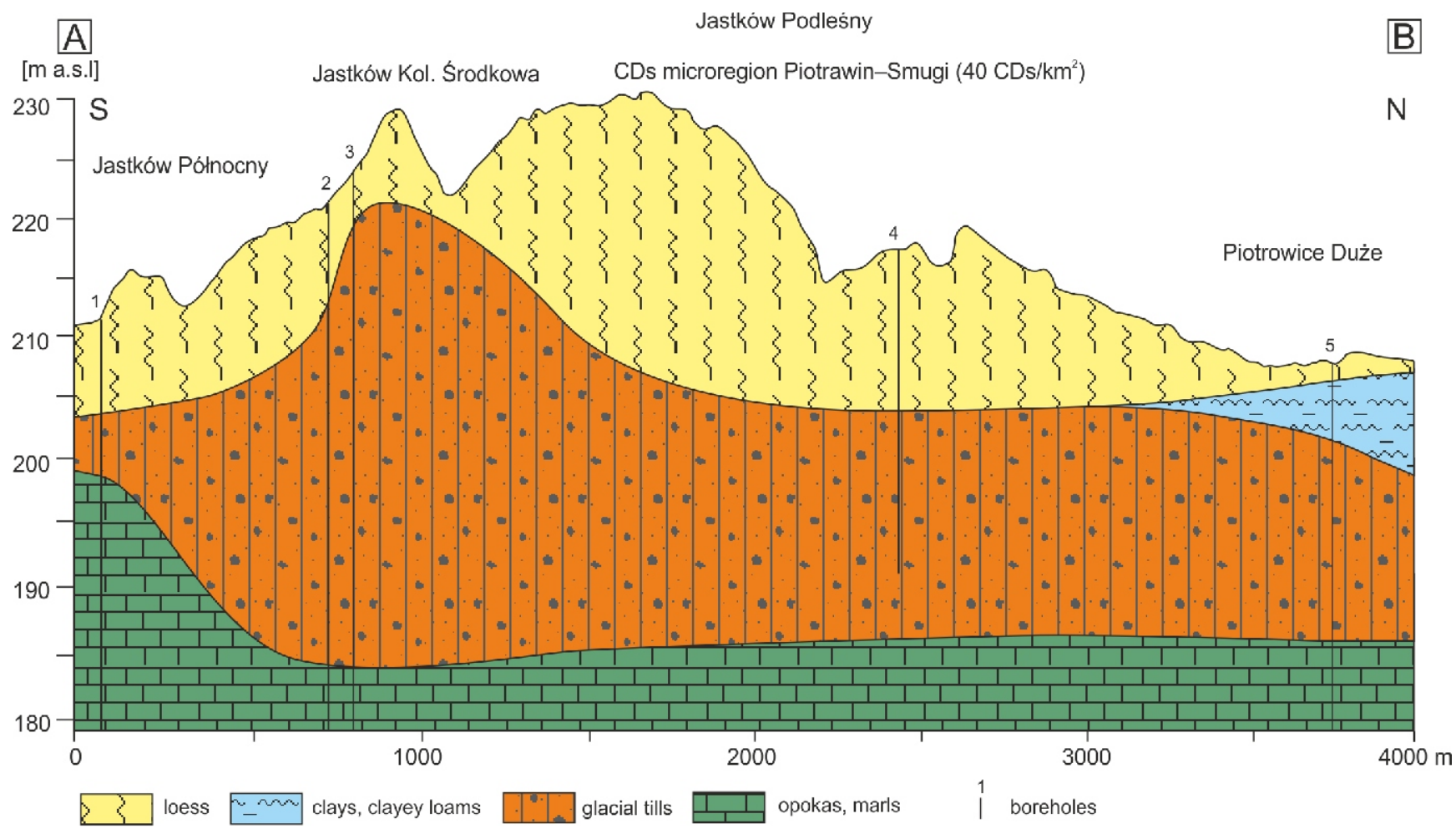

Fig. 6. Cross-section A-B in the eastern part of the Nałęczów Plateau

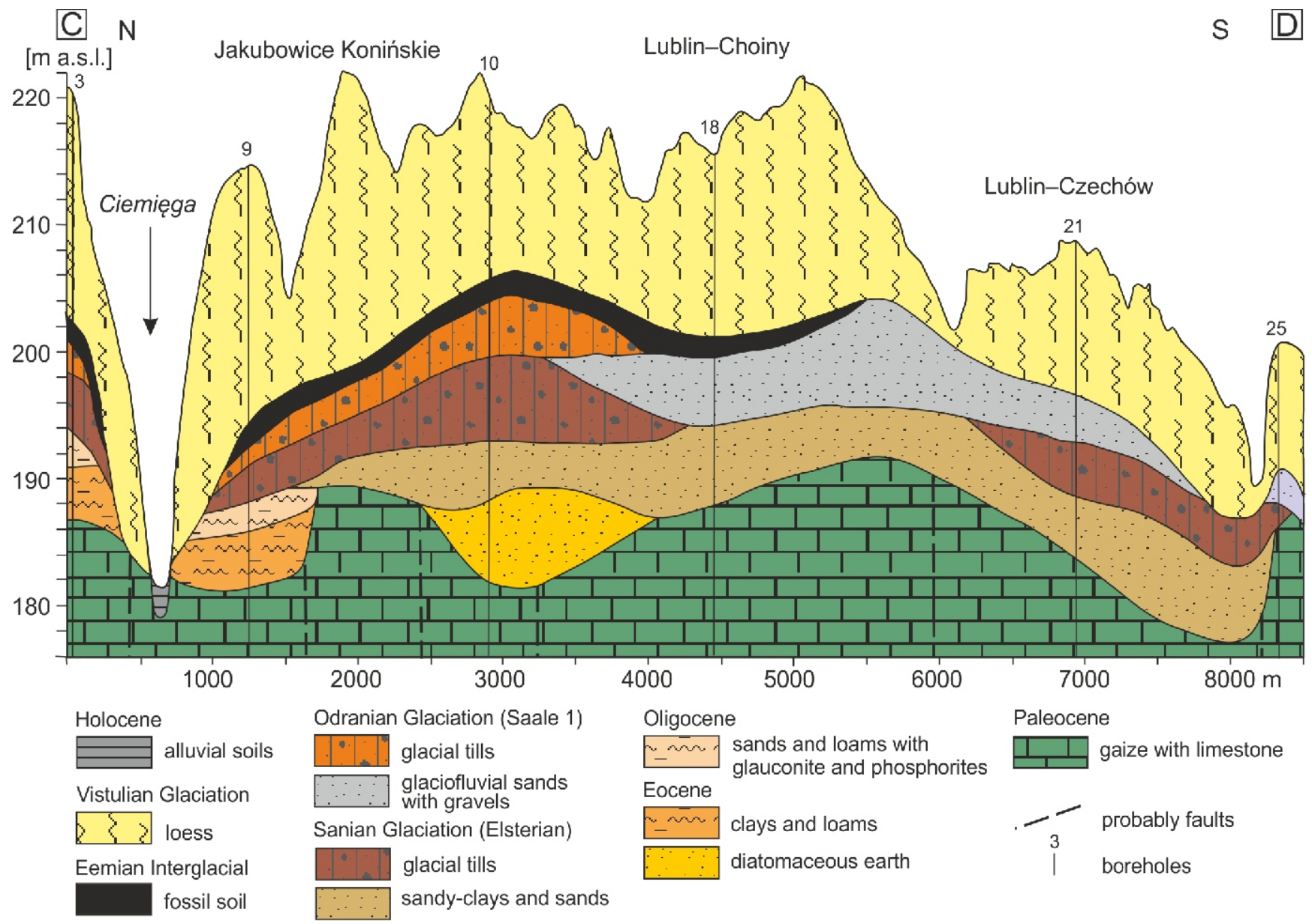

Fig. 7. Cross-section C-D in the eastern part of the Nałęczów Plateau (after Harasimiuk and Henkiel, 1981) 
[m a.s.I.]

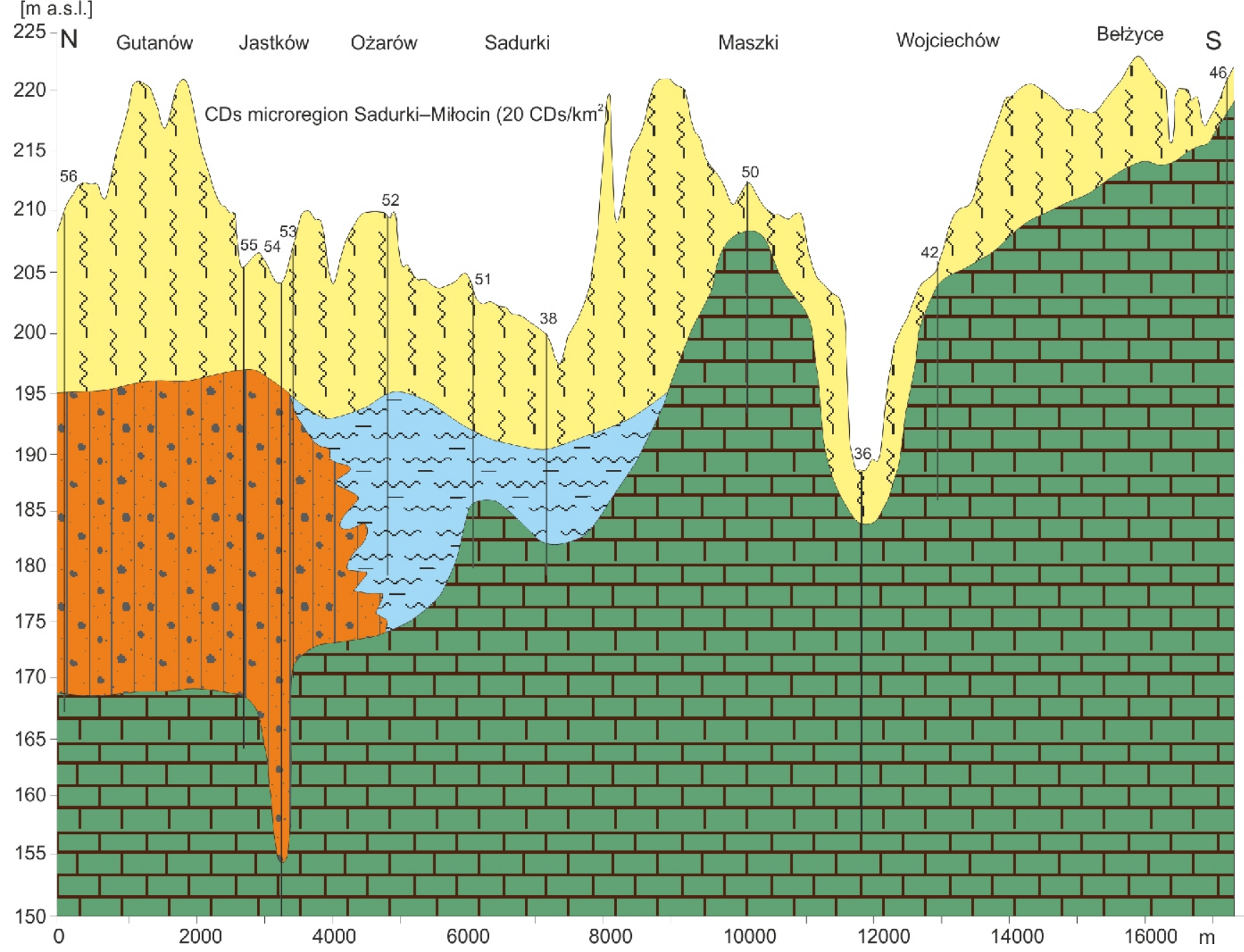

Fig. 8. Cross-section E-F in the eastern part of the Nałęczów Plateau

For explanation see Figure 6

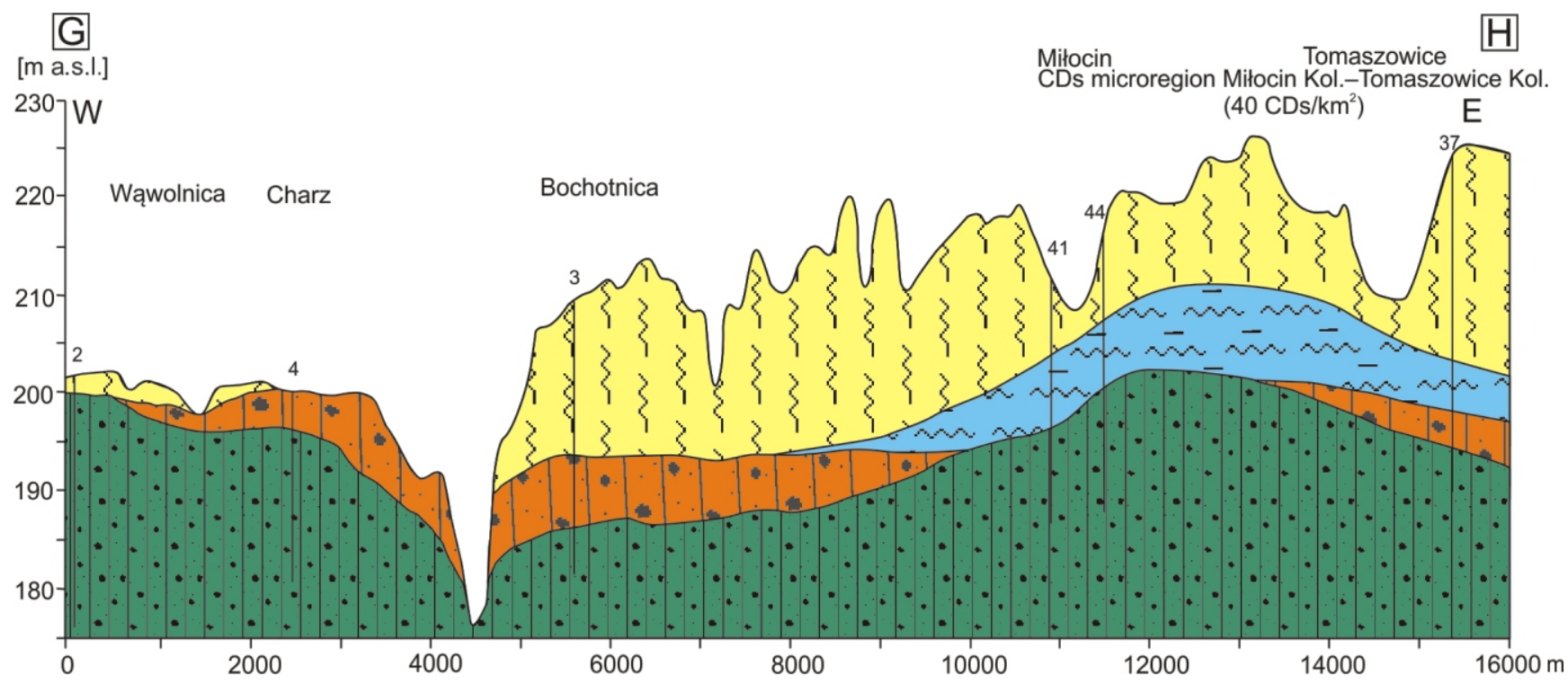

Fig. 9. Cross-section G-H in the eastern part of the Nałęczów Plateau

For explanation see Figure 6 


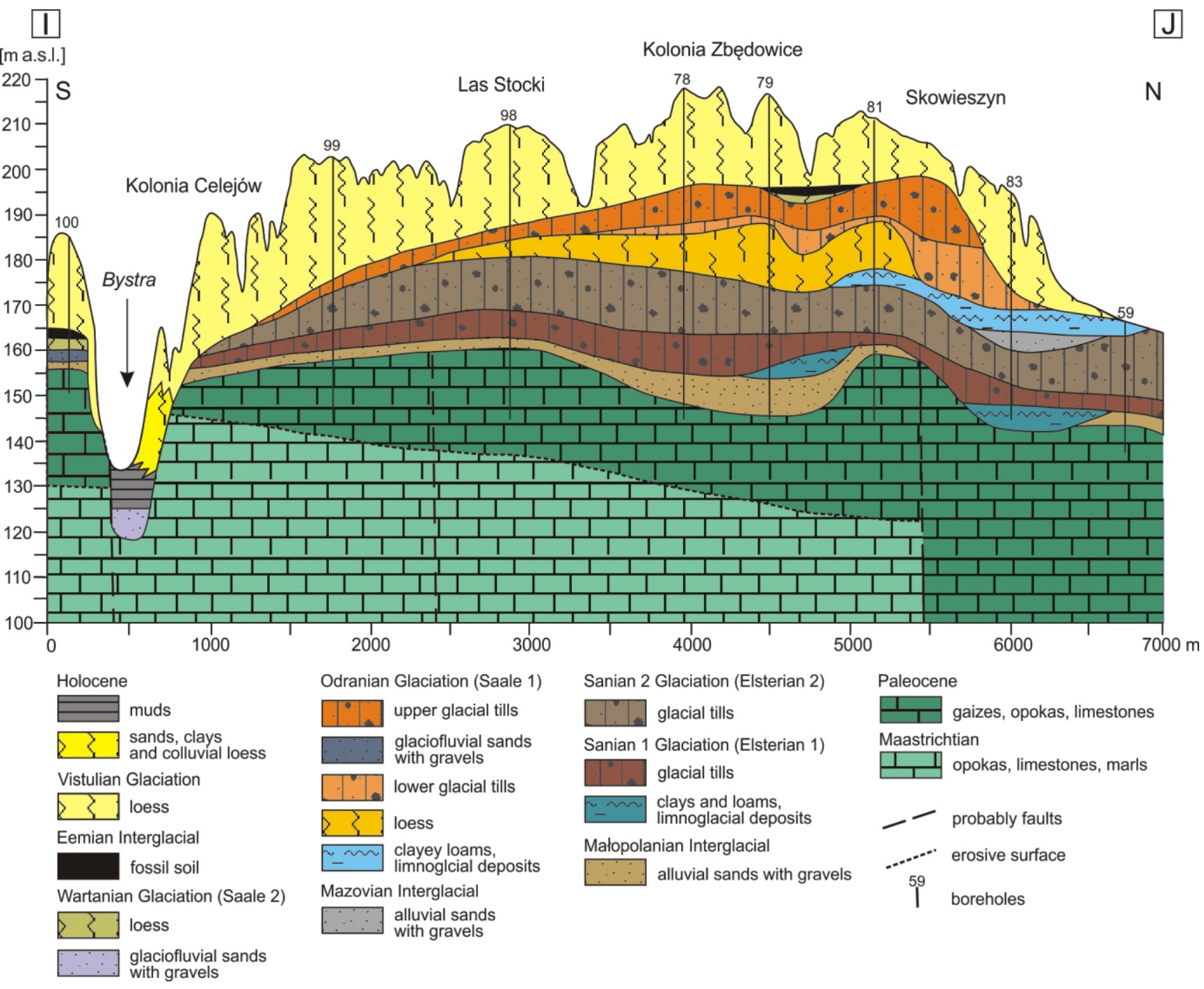

Fig. 10. Cross-section I-J in the western part of the Nałęczów Plateau

\section{DISCUSSION}

\section{CLIMATIC CONDITIONS OF THE LAST GLACIAL}

The climate in Europe was not stable during the Last Glacial, with numerous warmer and cooler episodes of varying magnitude associated with Heinrich and/or Dansgaard-Oeschger events (Vandenberghe and Pissart, 1993; Van Vliet-Lanoë and Hallegouët, 2001; Marks et al., 2016).

Due to the lowering of the sea level starting at the end of Eemian Interglacial and continuing during the Vistulian, the Gulf Stream in the North Atlantic weakened. This change resulted in a more continental climate, especially in Western Europe (Marks et al., 2016). In the Early Glacial (MIS 5d-a) permafrost conditions with lower temperature and decreased precipitation during the stadials Herning (MIS $5 \mathrm{~d}$ ) and Rederstall (MIS $5 \mathrm{~b}$ ) have been inferred in the Netherlands and Belgium (Kühl et al., 2007). For these stadials, the mean temperature in July was relatively high, $\sim 12-17^{\circ} \mathrm{C}$, and the mean temperature in January was -12 to $-19^{\circ} \mathrm{C}$. The precipitation was $500 \mathrm{~mm}$. For the interstadials Brørup and Odderade, the annual precipitation was $\sim 100 \mathrm{~mm}$ higher than in the stadials mentioned above. In the summer, the mean temperature reached $18^{\circ} \mathrm{C}$ and in the winter it dropped to $-15^{\circ} \mathrm{C}$ (Kühl et al., 2007). According to
Marks et al. (2016) there is no evidence of continuous permafrost development during the Early Glacial in Poland. The first, slight, stage of Vistulian loess accumulation took place in the Early Glacial in eastern Poland with steppe-tundra vegetation (Maruszczak, 1991, 2001). According to Jary and Ciszek (2013), there is no conclusive evidence of Early Vistulian loess deposition in the west of Poland.

In the Early Pleniglacial (MIS 4), the mean annual temperatures probably dropped below $-7^{\circ} \mathrm{C}$. A strong continental, arid climate with wind activity has been inferred for Central and Northern Europe (Helmens, 2014) and Eastern Europe (Henriksen et al., 2008). Ice-wedge pseudomorphs and cryoturbations are evidence of continuous permafrost in Northwestern Europe (Haesaerts and Van Vliet-Lanoë, 1981; Vandenberghe, 1985; Van Vliet-Lanoë, 1991; Vandenberghe and Pissart, 1993) and in Poland (Marks et al., 2016). In MIS 4/3 Jary (2009) identified the first Vistulian phase of permafrost disappearance based on the position of ice-wedge pseudomorphs.

In the Middle Pleniglacial (MIS 3), the mean temperature in the warmest month was around $10^{\circ}$ and in the coldest month, it ranged between -27 and $-20^{\circ} \mathrm{C}$. The annual temperature range was $30-38^{\circ} \mathrm{C}$. This indicates an extremely continental climate in Europe with active aeolian processes (Marks et al., 
2016). Two main phases of permafrost development and ice wedge formation at 60 and $28 \mathrm{ka} \mathrm{BP}$ in Central Europe were documented by Van Vliet-Lanoë (1989). In the loess belt, very few occurrences of ice-wedge casts younger than 36 ka BP have been found (Haesaerts and Van Vliet-Lanoë, 1981; Vandenberghe and Pissart, 1993). In Poland the first generation of ice wedges developed in the Middle Plenivistulian (Marks et al., 2016). Between the periglacial phases, there were intervals with milder climate with relatively high temperatures and rainfall (Helmens, 2014). During these intervals, at 38 ka BP and 27 ka BP (Van Vliet-Lanoë and Langohr, 1981; Van Vliet-Lanoë, 1998) or 30 ka BP (Marks et al., 2016), fluvial activity, thermokarst processes and pedogenesis developed. The inferred steppe-tundra vegetation in Central Europe during the MIS 3 stadials indicates strong continental conditions and suggests relatively warm, short summers and long, very cold winters (Helmens, 2014). Maruszczak (1991, 2001) suggested that, in the Middle Pleniglacial, loess was deposited in the period from 50 to $28 \mathrm{ka} \mathrm{BP}$. An extremely continental climate during the Hasselo stadial (41-38 kyr BP) in Western Europe has been documented (Huijzer and Isarin, 1997). Maruszczak (1991) suggested that in the period from 32 to $28 \mathrm{ka} \mathrm{BP}$, subarctic gley or brown soil developed on the Polish loess in an arid climate. In Polish loess profiles, there is no clear evidence of permafrost disappearance in this period.

Maximum cold with the culmination of continentality characterize the Late Pleniglacial (MIS 2; 27-13 ka BP). Traces of periglacial structures are very common in Europe, not only in loess subsoil (see references in Vandenberghe and Pissart, 1993). The occurrence of forms such as ice-wedge casts, cryoturbation structures or remnants of pingos indicate the occurrence of continuous permafrost at that time. The mean annual temperatures dropped below $-8^{\circ} \mathrm{C}$. The mean temperatures in the warmest month ranged from 9 to $11^{\circ} \mathrm{C}$, and in the coldest month, from -25 to $-20^{\circ} \mathrm{C}$. As a consequence, the annual temperature range was between 28 and $33^{\circ} \mathrm{C}$, indicating a high degree of continentality at that time. During this period annual precipitation was low: $250-300 \mathrm{~mm}$ in southern Poland (Starkel, 1988). There is ample evidence of aeolian activity during the intervals $27-20 \mathrm{ka} \mathrm{BP}$ and $17-13 \mathrm{ka}$ as a result of dry conditions in the northwestern European lowlands (Huijzer and Vandenberghe, 1998). In Poland, the main, third, stage of Vistulian loess accumulation took place. The melting of ice wedges started 15-14 ka BP, before loess accumulation decreased (Maruszczak, 1991). In Central Europe, permafrost may have persisted until the end of the Pleniglacial and Late Glacial (Van Vliet-Lanoë, 1991; Kozarski, 1995).

In the Last Glacial (Permafrost) Maximum (20-18 ka BP), ice-wedge polygons, 15-20 $\mathrm{m}$ in diameter, developed on the East European Plain. In southwestern France, the diameters of the past polygonal network in Pleistocene permafrost in silty deposits range from 10 to $20 \mathrm{~m}$ (Bertran et al., 2013; Andrieux et al., 2015). In Denmark, the most frequently documented diameters of the past polygonal network range between 10 and $15 \mathrm{~m}$, rarely exceeding $25 \mathrm{~m}$ (Last Glacial; Svensson, 1982). In northern Belgium (Flanders), a former polygonal network with diameters ranging from 6.5 to $>11 \mathrm{~m}$ has been documented in various sedimentary lithofacies (sand, clay; Ghysels and Heyse, 2006). In central western Poland, several principal types of polygon geometry have been documented within glacial tills: the largest ones have diameters ranging between 30 and $60 \mathrm{~m}$ (max. $67 \mathrm{~m}$ ), and the smaller ones have diameters of 5 to $20 \mathrm{~m}, 5$ to $30 \mathrm{~m}$, and 5 to $40 \mathrm{~m}$ (Ewartowski et al., 2016). In loess areas, the diameters of the Last Glacial polygonal network ranged between 20 and 25 m (Maruszczak, 1991; Jary, 2009). In the north, the ice wedges reached the maximum depth of $4-5 \mathrm{~m}$. In the south, their depth decreased gradually to $2.0-2.5 \mathrm{~m}$. The mean annual ground surface temperatures were usually -5 to $-7^{\circ} \mathrm{C}$, or lower, similar to the current temperatures in the northern part of the continuous permafrost zone in Siberia (Vandenberghe et al., 2014).

The Late Glacial is characterized by a series of marked climatic fluctuations. Abrupt climate changes took place in the Bøling (12.7-10.9 ka BP). The mean July temperature reached $16-18^{\circ} \mathrm{C}$ and mainly Betula-Pinus forests existed in Poland and NW Europe (Paus, 1995). During the Younger Dryas climatic event, 10.9-10.1 kyr BP, the climate conditions resembled those during glacial times with continental steppe tundra vegetation (Isarin and Renssen, 1999). The weather during winters in the Younger Dryas in northwestern Europe was characterized by very frequent storms, bringing a mixture of very cold $\left(\sim-30\right.$ to $\left.-35^{\circ} \mathrm{C}\right)$ and relatively dry air masses originating over the sea ice and relatively humid air from the open ocean (4 to $-1.9^{\circ} \mathrm{C}$ ). Most precipitation was probably in the form of snow. The thick snow cover may have prevented the formation of periglacial thermal contraction features in Poland (Isarin and Renssen, 1999). In northwestern, Central and Eastern Europe, extensive aeolian activity took place leading to the formation of dunes or a remodelling of the existing forms (Henriksen et al., 2008). During the Younger Dryas, summer temperatures in NW Europe ranged from $8^{\circ} \mathrm{C}$ in the northern part to $16^{\circ} \mathrm{C}$ in the southern part. The mean annual temperature ranged from -10 to $-8^{\circ} \mathrm{C}$. The mean January temperatures ranged between -20 and $-15^{\circ} \mathrm{C}$ (Isarin and Renssen, 1999). In the coldest period of the Younger Dryas, the modelled southern limit of continuous permafrost at low altitude reached $\sim 54^{\circ} \mathrm{N}$ (Isarin, 1997). Discontinuous permafrost occurred between 54 and $50^{\circ} \mathrm{N}$ in eastern Poland, among other regions. Ice-wedge casts occur as an exception and are poorly developed (Vandenberghe et al., 1987). Even on the large loess plateaus which form a favourable substratum for wedge development, no ice-wedge casts from the Younger Dryas have yet been recorded in Europe (Vandenberghe and Pissart, 1993). In sandy deposits in central Poland, small ice-wedge pseudomorphs were documented by Kasse et al. (1998). In the NW European lowlands, sporadic or discontinuous permafrost occurred in the Younger Dryas (Vandenberghe and Pissart, 1993). Pingos and palsas were developing in some areas in that period (Pissart, 1985, 2010).

The last major phase of Pleistocene permafrost degradation started probably in the early Bölling and continued in successively warmer phases (Vandenberghe et al., 2014). This is supported by Jary (2009) who concluded that the second phase of permafrost disappearance in the loess areas of Poland occurred in MIS 2/1 ( 12 ka BP). According to evidence of local geological conditions, complete degradation of permafrost in northern Poland occurred in the Preboreal period (Błaszkiewicz, 2011).

ICE CONTENT IN THE UPPER PART OF PAST PERMAFROST ON THE NAŁĘCZÓW PLATEAU: THE IMPORTANCE OF THE LOESS COVER AND CLIMATE

The ice-rich zone lies below the base of the active layer and at the top of permafrost, especially in the upper $0.5-2.0 \mathrm{~m}$ (Yershov, 1998). The depth of the ice-rich layer results from the migration of water in the direction along which ground temperature decreases in response to an imposed thermal gradient. The typical distribution of ground ice with depth shows that in this subsurface ice-rich zone, ground ice content reaches $60 \%$ and decreases downwards to over $40 \%$ at a depth of $10 \mathrm{~m}$ (French, 2007). In Alaska and the Northwestern Territories of Canada, only the upper part of permafrost (5-10 m) has a high 
segregated ice content. Ice wedges $1-3 \mathrm{~m}$ wide and comprising $10-30 \%$ of the upper $6 \mathrm{~m}$ are more common (Black, 1969 Brown and Sellmann, 1973; Pollard and French, 1980). A study from Canada (the Mackenzie River delta) generally shows a decrease in ice content from the surface to a depth of 3-7 $\mathrm{m}$ where ice content can reach up to $80 \%$ of the total volume (Mackay, 1966).

According to French (2007), the nature of the ground and especially its frost susceptibility, thermal conductivity and mechanical behaviour as well as water content are also key parameters influencing permafrost. The mean total volumetric ice content depends on lithological variations in the sediments, and ranges from $43 \%$ in aeolian sand to $80 \%$ in silt in northern Alaska (Kanevskiy et al., 2013). Silty soils such as loess are susceptible to frost and constitute a substratum favourable for ice concentration (Penner and Goodrich, 1981). In these sediments, the downwards-advancing freezing front causes water to be drawn upwards to the advancing freezing plane by cryosuction, first to form pore ice when it reaches the freezing plane (frozen fringe), and subsequently to form segregated ice lenses (French, 2007). In the upper part of the sediment, low overburden pressures result in a better development of ice lenses. At higher pressures and under similar thermal gradients, these tend to develop into more diffuse bands (Penner and Goodrich, 1981). The upper part of permafrost is the richest in ice concentrations in the form of segregated ice (Czudek and Demek, 1970; Van Vliet-Lanoë and Langohr, 1981; Shur 1988). Features formed by ice segregation cannot occur at depths originally $>40 \mathrm{~m}$ (Washburn, 1979). During unsteady heat flow, variations in segregation, freezing temperature and overall permeability of the frozen fringe with temperature produce rhythmic ice banding in fine-grained soils (Konrad and Morgenstern, 1980).

Thermal contraction cracks are tensile fractures produced by thermal stresses (i.e., the rapid drop to subzero temperatures) in ice-rich permafrost. Ice-wedge pseudomorphs are very common past periglacial features in the European loess belt (Van Vliet-Lanoë, 1989; Bertran et al., 2013; Jary and Ciszek, 2013). Frost-cracking and ice-wedge growth have been described by many authors (Lachenbruch, 1966; Mackay, 1974 1990; Harry and Goździk, 1988; Murton, 1996; Yershov, 1998; Murton et al., 2000; Van Vliet-Lanoë, 2005; French, 2007 French and Shur, 2010). Lachenbruch (1966) suggested that the size of polygons depends on lithology (material strength), moisture content and crack depth. Climate conditions are also very important as regards the dimensions of the polygonal network. Yershow (1998) found that the greater the thermal amplitude, the smaller the distance between fractures and the smaller the polygons. Therefore, in regions with extreme continental climate, progressively smaller subdivisions of the original polygonal network occur (numerous frost fractures spaced at $0.5-2 \mathrm{~m}$ to $10-12 \mathrm{~m}$ ). In conditions of less continental climate, frost polygons are formed, with cracks spaced at 20-40 m and even $50-80 \mathrm{~m}$. Those progressively smaller subdivisions of the original polygonal network occur as temperature decreases.

The loess cover on the Nałęczów Plateau consists of patches of varying thickness (Harasimiuk and Henkiel, 1978). In the eastern part of the region, the thickness of the loess cover ranges from a few to ten or so metres, and in the western part from a few $m$ to $>20 \mathrm{~m}$ (Figs. 2 and 3 ). It is assumed that the loess patches are determined by the distribution of moisture in the ground depending on the lithological properties of the sediments (Cegła, 1969) and the varied relief under the loess cover (Harasimiuk and Henkiel, 1978). On the Nałęczów Plateau, there is no evidence of spatial variation in the lithological properties of the loess that could influence spatial variation in the frost susceptibility of the loess cover in the region studied. Slight vertical variation in the lithological properties was documented, i.e. between particular layers of loess (Harasimiuk, 1987; Maruszczak, 1991). This may have had a small impact on the vertical variation of frost susceptibility in the loess cover. The top loess layers $(\mathrm{LMg})$ have a lower content of the finest fraction and better sorting. In periglacial conditions, this may have led to the slightly greater ground ice content in the top parts of the loess cover

Pleniglacial permafrost in Europe had a regionally varied ice content mainly depending on precipitation and on the thickness of the snow cover (Van Vliet-Lanoë, 2005). Very small ice-wedge pseudomorphs $(2-2.5 \mathrm{~m})$ commonly observed in loess in Western Europe suggest generally ice-poor permafrost in the Pleniglacial period. The ice wedges represent short lived-events (centuries), very dry or sporadically active environments (Van Vliet-Lanoë and Hallegouët, 2001; Van VlietLanoë, 2005). In Poland and Eastern Europe, two generations of ice wedges have generally been distinguished, associated with the Lower (MIS 4) and Upper Plenivistulian (MIS 2). In these periods, the climate in Eastern Europe was more continental than in Western Europe, with the thermal gradient increasing from west to east (Huijzer and Isarin, 1997; Kasse et al., 2003; Marks et al., 2016). In the loess areas of Poland, ice wedges from these periods reach 3-4 $\mathrm{m}$ and over $5 \mathrm{~m}$ in western Ukraine (Jary, 2009; Jary and Ciszek, 2013). The largest ice wedges developed during the Upper Plenivistulian, suggesting ice-rich permafrost associated with the upper part of the loess cover (LMg). In the beginning of the each period of permafrost aggradation, the precipitation was higher as cryoturbation/frost creep horizons have been recorded in the loess areas of Poland (Jary, 2009; Jary and Ciszek, 2013). This had an impact on the ice enrichment of permafrost in these periods. The warming events of interstadials during glacial periods resulted in increased precipitation. The number of periglacial horizons within loess-soil sequences, and their morphological features, vary, depending on their geographical settings (W-E and N-S directions). In the loess profiles of Poland and Ukraine, 4-6 gley horizons are recorded. This suggests the impact of local or regional oscillations on the number of depositional cycles related to the Heinrich or Dansgaard-Oeschger events (Jary and Ciszek, 2013). The short warmest and wettest periods (interstadials) were probably more frequent in the east. A more continental climate, especially during interstadials (Marks et al., 2016), may imply the occurrence of torrential precipitation events during warm summers. This allowed a deepening of the permafrost table as well as its ice enrichment. The higher frequency of climate fluctuations from west to east probably contributed to the ice enrichment of the permafrost. This suggests that Pleniglacial permafrost in Central and Eastern Europe may have been richer in ice than in Western Europe.

Kasse and Vandenberghe (1998) suggested that the distribution of ice wedges depended on local humid conditions linked with the topography. Van Vliet-Lanoë (2005) pointed out the importance of local ground moisture for the development of ice-wedge polygons. High ice content is basically necessary to induce efficient thermal cracking in sediments. Wet depressions are rich in ice and this allows the development of the smallest polygons. Ghysel and Heyse (2006), who studied Pleistocene ice-wedge pseudomorphs in Flanders (Belgium), also found that ice wedges were formed in humid depressions. This is supported by the investigations of Ewartowski et al. (2016) who linked the locations of ice-wedge pseudomorphs with the depressions between ice-cored moraine ridges. The flat and poorly dissected accumulation surfaces of the loess plateaux are a typical feature of the landscape on the eastern 
part of the Nałęczów Plateau. Their presence created morphological predispositions for the development of polygonal crack networks in this part of the region. On the western part of the Nałęczów Plateau, the loess plateau tops have the form of small patches due to the strong dissection of the area by deep valleys. This has affected the drainage and limited the development of polygonal crack networks with ice wedges in past permafrost. Once a crack/ice wedge exists, it forms a weakness at depth that is re-used by epigenetic thermal cracking (Lachenbruch, 1966; Goehring, 2013).

\section{THE IMPACT OF THE DEPOSITS UNDERLYING THE LOESS COVER ON ICE CONTENT IN THE UPPER PART OF PAST PERMAFROST ON THE NAŁĘCZÓW PLATEAU}

During the Plenivistulian, ice content in the upper part of past permafrost on the Nałęczów Plateau depended on sedimentary deposits of different grain size underlying the loess cover. Highly frost-susceptible material, besides silts, includes clay, mostly in waterlogged conditions. Drainage is better in sandy or gravely sands (Van Vliet-Lanoë, 2005). The thermal conductivity of clays is smaller than that of loess or sands, both when frozen and unfrozen (French, 2007). Therefore, during permafrost aggradation, glacial tills could freeze later than the surrounding coarse-grained deposits. As a result of cryosuction, water from glacial tills migrated up into the freezing loess, enriching it in ice. Frozen glacial tills are rich in ice as they have well-developed ice lensing (Van Vliet-Lanoë and Hallegouët, 2001). Given their lower thermal conductivity, glacial tills underlying the loess preserved permafrost for a longer time than the surrounding coarse-grained deposits. Coarsegrained tills may also include injected ice bodies. Under the influence of the thermal gradient, the ice contained by glacial tills may have migrated in the vapour phase into the overlying loess. Hence, the loess cover above glacial tills in the region studied was enriched in ice compared with the loess above other sedimentary deposits under past permafrost conditions.

The amount of ice present in the permafrost is also a function of the drainage conditions of the formerly unfrozen ground (Van Vliet-Lanoë and Langohr, 1981). Kanevskiy et al. (2013) in Alaska suggested that poorly-drained areas have a higher content of ground ice in permafrost than do well-drained areas. Morgenstern et al. (2013) in Eastern Siberia suggested that good surface drainage conditions (for example as a result of the dissection of some areas) have an impact on the formation of ground ice and causes a reduction of total ice content in permafrost.

In the region studied, the poor drainage is influenced by the limited dissection of the surface as well as by the presence of poorly permeable deposits under the loess cover along with a limited variation of relief. The presence of poorly permeable sedimentary deposits (tills, clays, clayey loams) beneath the loess reduced the drainage of water and contributed to a higher water content in the underlying loess layer. In consequence, the volume of ice in the loess cover (upper part of permafrost) increased. Thick and homogeneous layers of glacial till, with a small variation of relief under the loess cover, predominate in the eastern part of the region (Figs. 4 and 5). Extensive areas with geological structure of this type occur north of the Ciemięga valley, on the proximal side of the loess-covered recessional moraine ridge, between the localities of Bogucin and Smugi (Figs. 4 and 5). They also occur locally in correspondence with glacial till patches in the Ciemięga-Czechówka interfluve zone (Figs. 4 and 5).

The area in the vicinity of Sadurki, Ożarów and Tomaszowice is poorly drained due to the occurrence of poorly permeable layers (clayey loams and clays) with a small variation of relief (Figs. 4 and 5). Smaller areas with similar conditions are located on the western part of the Nałęczów Plateau in the vicinity of Zażuk, Klementowice and Karmanowice (Figs. 4 and 5). Sandy deposits or fractured bedrock under the loess cover provided good drainage. The higher-lying loess cover contains less water and, in conditions of a frozen substrate, a smaller amount of ground ice. Patches of sandy glaciofluvial deposits underlying the loess cover predominate between the Bystrzyca and Potok Konopnicki rivers and south of the Bystra River valley. Due to the strong dissection of this area by valley systems, the relative elevation under the loess cover reaches $30 \mathrm{~m}$ here (Fig. 5).

The high variation in the relief of the deposits underlying the loess cover leads to the occurrence of considerable hydraulic gradients and, consequently, good water drainage conditions. The presence of a dense network of deep polygenetic valleys incised into the bedrock (Gardziel et al., 2006; Gawrysiak and Harasimiuk, 2012; Figs. 1 and 5) has a permanent impact on the good water drainage conditions on the western part of the Nałęczów Plateau (Figs. 1 and 5). Nowadays, the intense, geologically determined drainage of groundwater is seen from the presence of numerous piping forms in some areas of the western part of the Nałęczów Plateau (Gardziel et al., 2006). Despite the presence of thick, poorly permeable layers of glacial till, good water drainage conditions did not favour the concentration of ice and thus limited ice wedge formation in past permafrost.

\section{THE AGE OF THERMOKARST CLOSED DEPRESSIONS ON THE NAŁECZÓW PLATEAU}

The stratigraphic study of Pleistocene ice-wedge casts reveals a cyclic permafrost development and disappearance in Europe controlled by the Heinrich and Dansgaard-Oeschger events. Cyclic events of ice wedge growth - wedge decay loess deposition, occurred several times during the Last Glaciation in Western Europe (Van Vliet-Lanoë, 1998; Van Vliet-Lanoë and Hallegouët, 2001; Van Vliet-Lanoë et al., 2017).

Thermokarst may have occurred repeatedly during the Last Glacial period in the area studied. It spread during a few warm periods between phases of strong continental climate related to permafrost expansion. Fluvial activity and organic sedimentation from these warm periods have been recorded in many profiles in Poland (Marks et al., 2016). In the loess areas of Poland, fossil soils have been linked with these periods (Jary, 2009).

In the loess areas of Poland and western Ukraine, a repeated expansion and disappearance of permafrost during the Last Glacial period has been documented (Jary, 2009). Permafrost and ice-wedges melted between the Lower and Middle Pleniglacial (MOIS 4/3) and between the Late Glacial and the Holocene (MIS 2/1; Jary, 2009). According to Van Vliet-Lanoë and Hallegouët (2001), thermokarst in Western Europe formed at $27 \mathrm{ka}$ and $12 \mathrm{ka}$, but was more frequent towards the east, in Poland and Russia. It can be caused by more frequent climate fluctuations recorded as more numerous periglacial horizons formed during the Late Plenivistulian in the loess areas of Eastern Europe. However, the correlation of these horizons is not unequivocal (Velichko et al., 1984; Jary, 2009).

The warm intervals Oerel and Glinde have been distinguished at the start of the Middle Plenivistulian (MIS 3) linked with a cold continental climate (Marks et al., 2016). In the loess profiles in Poland, a fossil soil horizon dated to $55-50$ ka and linked with the Oerel and Glinde warming events has been documented (Maruszczak, 1991). Warming periods at $\sim 38 \mathrm{ka}$, linked with the Hengelo Interstadial, and at about $30 \mathrm{ka}$, linked 
with the Denekamp Interstadial, have been recorded in profiles in Western Europe (Van Vliet-Lanoë and Hallegouët, 2001). In the loess profiles in Poland, soil formation took place between 32-28 ka, and in Russia between 32 and 24 ka (Velichko, 1990; Maruszczak, 1991; Jary, 2009). During the Hasselo stadial ( 40 ka), which preceded these interstadials, ice wedges formed in loess profiles in eastern Poland and in various deposits in central Poland (Maruszczak, 1991; Marks et al., 2016). In Russia and Ukraine, an interval with a more moderate climate, lasting 15-16 ka (Trubchevsk soil, Rivne soil), has been distinguished in the loess profiles (Velichko et al., 1984; Bogutsky, 1987). Below this horizon, ice-wedge pseudomorphs have been documented in Ukrainian loess profiles (Jary, 2009). This warming event, manifested as gley horizons, was also recorded in the loess profiles in Poland. Maruszczak (1991) correlates this horizon with the decay of large ice wedges which formed in the Upper Plenivistulian. During the Early Bølling (12.7 ka), the last phase of thermokarst occurred, in conjunction with the Upper Plenivistulian permafrost degradation.

Between two and four stages of thermokarst CDs development can be distinguished on the Nałęczów Plateau. The two main stages occurred in MIS 4/3 ( 58 or 55-50 ka Oerel and Glinde Interstadials) and MIS 2/1 ( 12 ka). These landforms may have developed also during the Denekamp Interstadial (32-28 ka) and $\sim 15 \mathrm{ka}$. The final stage of CDs formation in the Late Glacial is supported by the presence of Late Vistulian-Holocene fossil soils covered primary bottoms of the CDs studied (Figs. 2 and 3). Holocene colluvial deposits above these fossil soils have been documented.

A primary thermokarst microrelief with numerous CDs developed in the region studied during the first stage of MIS $4 / 3$ ( $~ 58$ or $55-50 \mathrm{ka})$. In the next period of permafrost restoration and loess deposition, a polygonal network with ice wedges developed. The spatial distribution of polygonal networks with ice wedges corresponded with the local geological and topographic determinants. CDs from the older stage of thermokarst may have created favourable topographic conditions for the location of the junction of a younger generation of the polygonal networks. Thus, polygonal networks from different stages may have been partially superimposed. The persistence of polygonal networks and preference in the formation and development of subsequent generations of cracks was noted by Lachenbruch (1966) and Goehring (2013).

Repeated cycles of thermokarst CDs development, ice wedge restoration and loess deposition occurred several times during the Last Glaciation on the Nałęczów Plateau. They resulted in the development of at least two generations of superimposed thermokarst depressions. These forms are among the deeper CDs documented today on the Nałęczów Plateau. Smaller forms may have developed as a result of the decay of ice wedges during the single phases of thermokarst.

THE SCHEME OF GEOLOGICALLY CONTROLLED THERMOKARST CLOSED DEPRESSIONS DEVELOPMENT ON THE NAŁĘCZÓW PLATEAU

According to Black (1969), most CDs in Alaska are related to the thawing of ice wedges. Seppälä (1997) indicated that the ice wedge melting process initiates the development of depressions and gullies. Soloviev (1973) described alas depressions forming as a result of ice wedge melting in central Yakutia. The melting of ice wedges due to the accumulation of water above them is the main cause of thermokarst development in Siberia (Czudek and Demek, 1970). The forms developed depend on the amount of ground ice and its type. Flat shallow depressions develop in places with small amounts of ground ice or in places with segregated ice, or both. The melting of ice wedges as a process causing the formation of CDs on the Nałęczów Plateau was suggested by Kołodyńska-Gawrysiak et al. (2017). Structures of two ice-wedge pseudomorphs and lenticular structures deformed during permafrost melting were documented under the bottom of a CD (Fig. 11A, C). Faults caused by the thawing of ice wedges and ground subsidence are also visible (Fig. 11C). Decalcified loess occurs under the bottom of the $\mathrm{CD}$. The decalcification border falls steeply under the slopes of the CD. Reticulate structures were documented along the decalcification border (Fig. 11B) and also calcium carbonate concretions.

The intersections of fissure polygon networks, filled with ice wedges, were predisposed for the formation of thermokarst depressions (Fig. 12). This hypothesis is supported by the spatial distribution of closed depressions (based on LIDAR data) in conjunction with traces of cryogenic polygonal networks clearly visible on satellite photographs as well as documented by electrical resistivity surveys and georadar surveys (Fig. 12).

The formation and distribution of periglacial forms is influenced by many factors such as climatic conditions as well as local factors determining ice content in permafrost (French, 2007). The relation of climate and ecosystems (local factors) is important for the development and degradation of permafrost (Shur and Jorgenson, 2007; Toniolo et al., 2009; Ulrich et al., 2017). Local factors affecting the formation and development of thermokarst CDs in the study area include: the relief under the loess cover and spatial variation of ice content in past permafrost. This last factor is determined by the local geological conditions i.e. lithological features of sedimentary deposits under the loess cover and drainage conditions.

The study by Harasimiuk and Henkel (1978) indicated that the relief of glacigenic deposits underlying the loess cover of the Nałęczów Plateau (especially in areas with glacial tills) is characterized by the presence of depressions formed from the melting of blocks of dead ice (dead ice topography). These wet primary (glacigenic) closed depressions (see Piotrawin site in Fig. 3) were probably favourable both to successive loess deposition and to ice wedge development (Cegła, 1969). This suggests the impact of local microrelief on syngenetic ice wedge development. Epigenetic ice wedges have been documented in loess areas in Poland (Maruszczak, 1991, 2001; Jary, 2009). Jary (1996) observed that it is often impossible to identify the type of ice wedge due to its transformation during the melting of permafrost. He suggested that syngenetic ice wedges in the loess uplands of Poland developed during the Last Glacial. According to Jahn (1975), large syngenetic ice wedges developed in depressions where depositional processes prevailed.

In the study area, ice-rich permafrost with well-developed polygonal networks filled by ice wedges occurred in areas where the loess is not more than $10 \mathrm{~m}$ thick and is underlain by poorly permeable deposits (tills, clayey loams and clays) with small relative heights under the loess cover i.e. poorly drained (Figs. 4 and 5). The ice wedges (both epigenetic and syngenetic) may have formed in the loess covering depressions in glacigenic deposits (Fig. 13A). During each period of permafrost aggradation, junctions of polygonal networks with syngenetic ice wedges may have recurred at these locations (Fig. 13A). The most favourable location for thawing is at the junction of polygonal cracks, and small, deep pools of standing water may have existed at such locations (French, 2007). Surface water bodies above the melting ice-wedges warmed (latent heath of fusion) enough to perforate permafrost with numerous sinking ponds. In the study area, the repeated degradation of ice wedges (at least twice) at the junction resulted in 


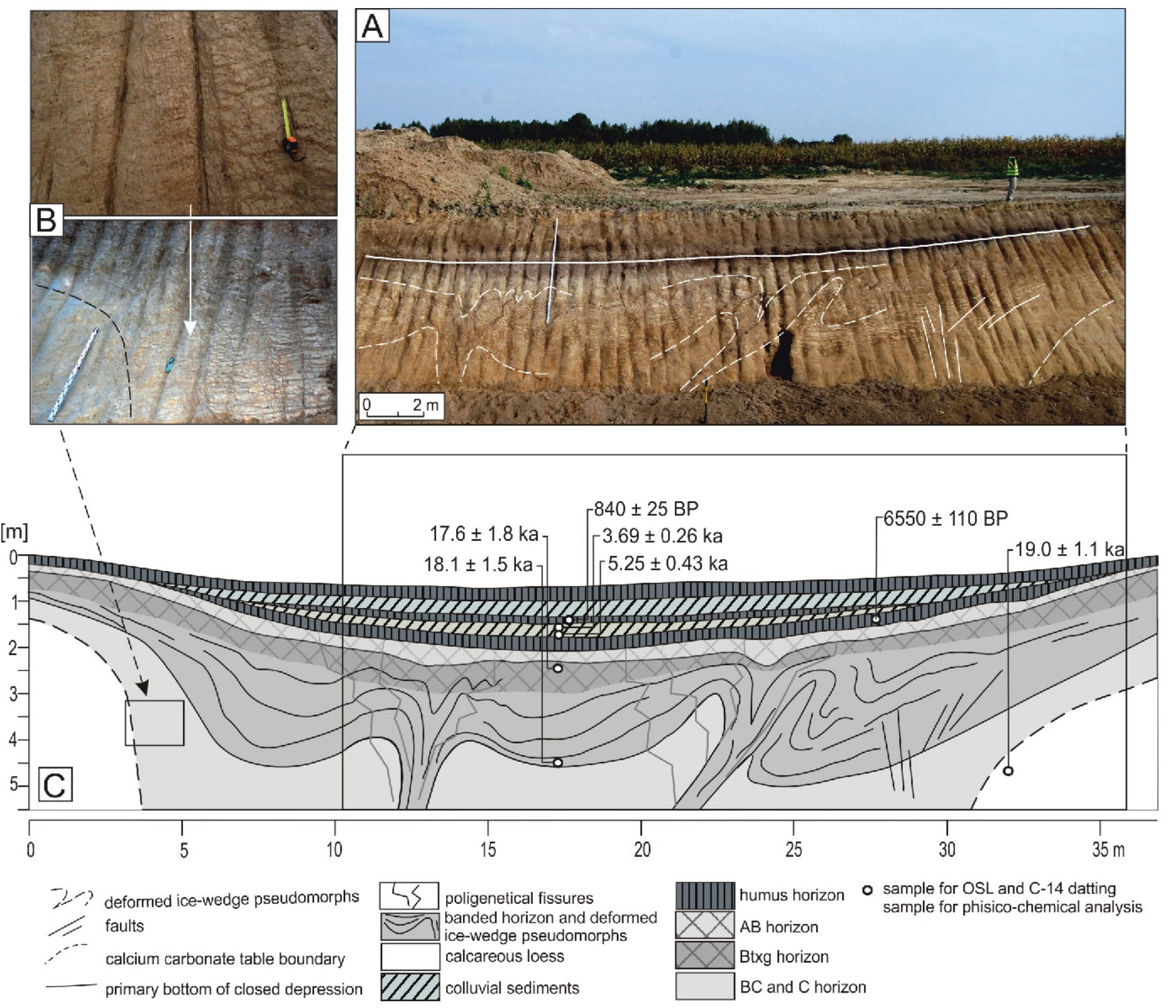

Fig. 11. Deformed ice-wedge pseudomorphs and permafrost thaw-related structures under the closed depression in the loess area near Jastków, E Poland (after Kołodyńska-Gawrysiak et al., 2017)

A, C - cross-sections of the studied closed depression; B - reticulate structures along the boundary of loess decalcification

deep decalcification, reaching the footwall of the loess cover or to depths of 10-15 m, depending on the geological and geomorphological conditions (Fig. 13). Such deep decalcification of the loess only under the CDs suggests that it started largely before the Holocene. Dissolution of calcium carbonate under the CDs occurred in several stages every time the superimposed ice wedges melted. Outside the CDs, the depth of the decalcification of the loess cover does not exceed $1.7 \mathrm{~m}$. The boundaries of loess decalcification are steep, almost vertical towards the bottom (Figs. 2, 3 and 11). Reticulate cryofabrics occur along the boundary of loess decalcification. Such structures form during the freezing of water-saturated sediments and reflect the position of the advancing freezing front (French and Shur, 2010). Each time, the polycyclic melting of ice-wedges resulted in ground subsidence.

In areas with a thicker loess cover $(\sim 20 \mathrm{~m})$, the presence of glacial tills, clayey loams or clays under the loess cover had a smaller impact on the formation of ice wedges (Fig. 13C). The thick loess cover masked the smallest features of the relief of the underlying deposits, preventing the formation of reproduced
CDs. (Fig. 13C). Ice wedges forming in such conditions had smaller dimensions than in the areas described above (Fig. 13A). This also results from the smaller amount of moisture at the top of the loess cover because the capillary rise in loess sediments is $\sim 20 \mathrm{~m}$ (Cegła, 1969).

In areas where a loess cover is underlain by sands or fractured bedrock, the geological conditions were less favourable to ice-rich permafrost and the formation of extensive polygonal crack networks with ice wedges (Fig. 13B, D). A greater amount of humidity accompanied the depressions formed in the underlying deposits and reproduced in the loess cover (Fig. 13B, D). Such places may have constituted junctions of the polygonal networks. It seems that ice wedges developing in such geological conditions reached smaller dimensions than in the case of a poorly permeable substrate.

It should be noted that thermokarst depressions formed not only as a result of the melting of ice wedges infilling the polygonal networks. Field observations of many geological exposures suggest that small thermokarst depressions (diameter of $\sim 20 \mathrm{~m}$ ) formed due to the melting of other forms of ground ice concentra- 

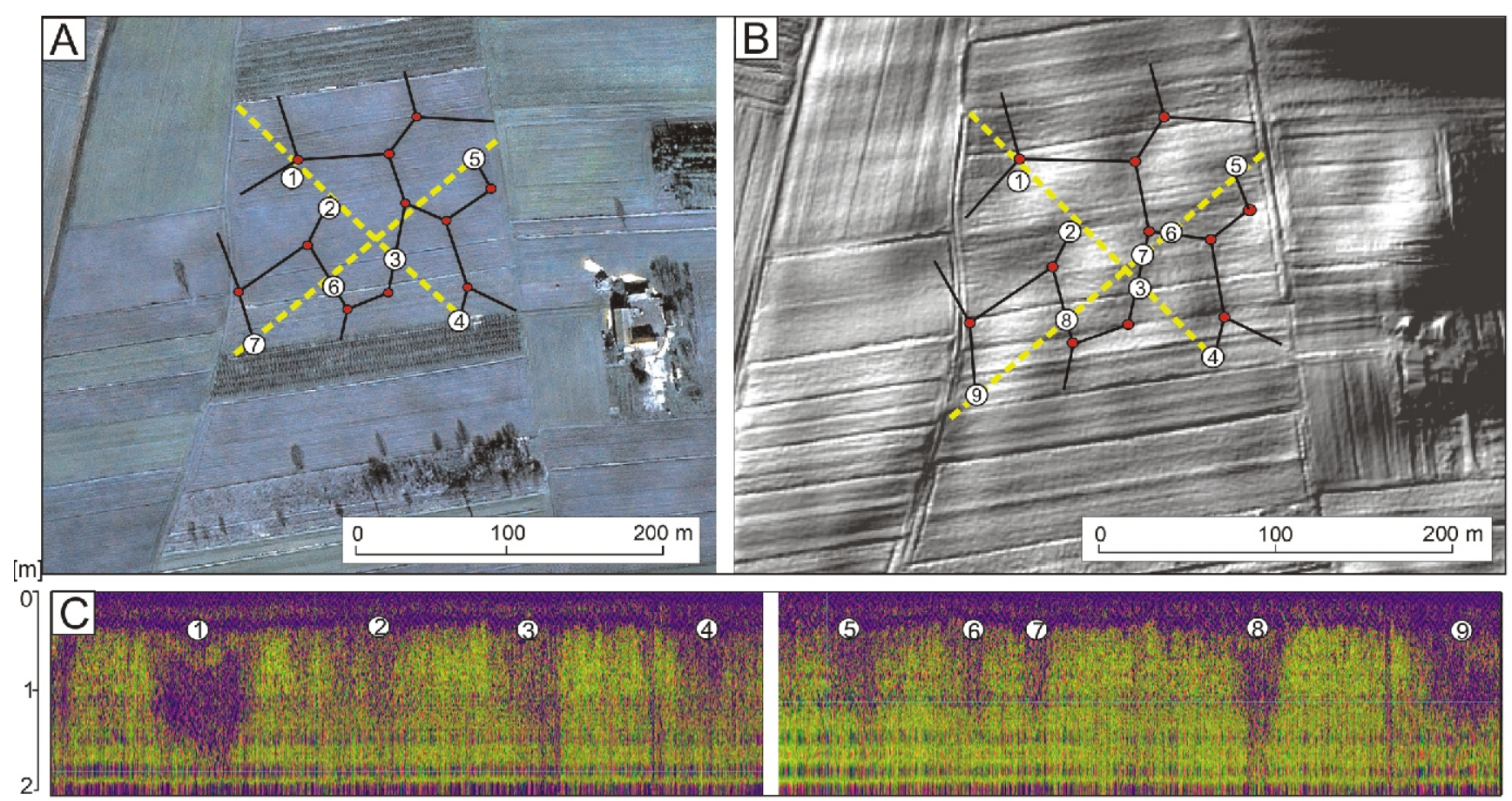

$\infty^{-}$location of the georadar profiles reconstructed past polygonal network

(7) number of ice-wedge pseudomorphs

Fig. 12. Reconstruction of fossil polygonal network

A - on satellite image (Pleiades, 17.02.2014); B - on a DEM derived from LIDAR data; C - on georadar profiles; an example from the Nałęczów Plateau (E Poland)

A

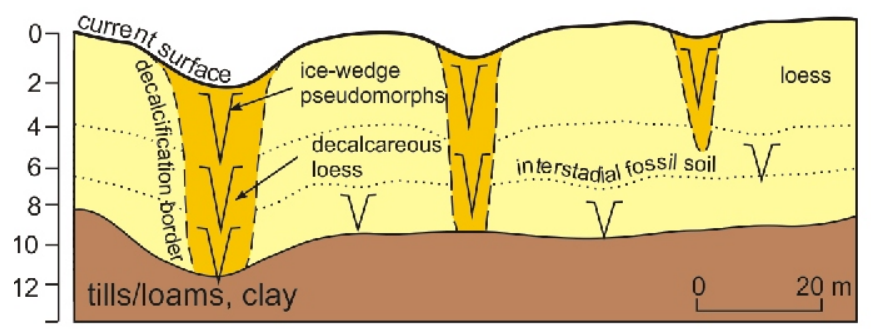

C

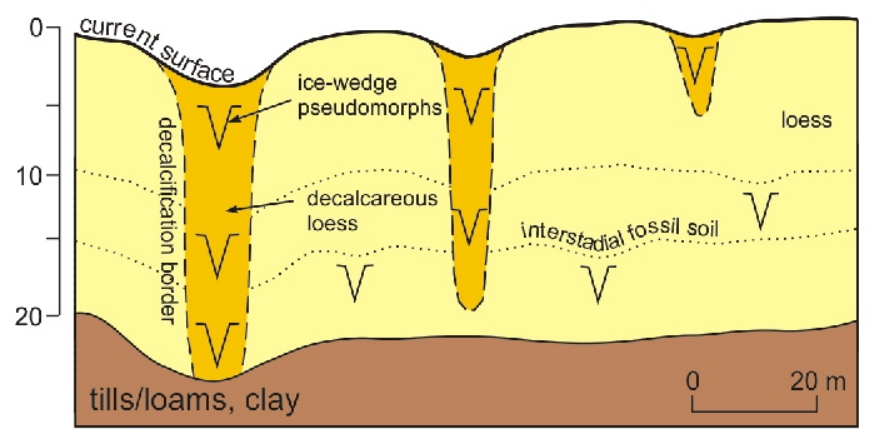

$\mathrm{B}$

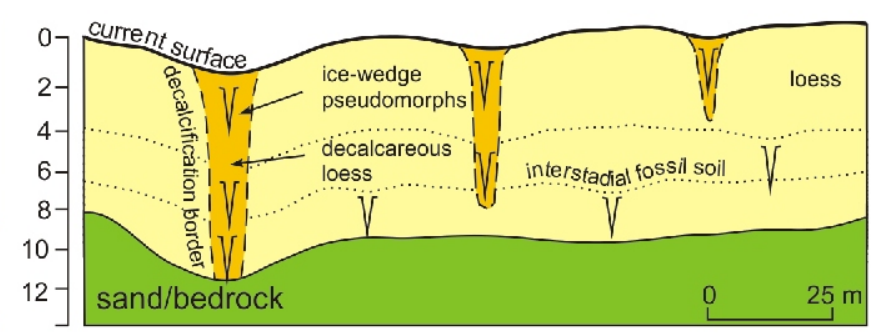

D

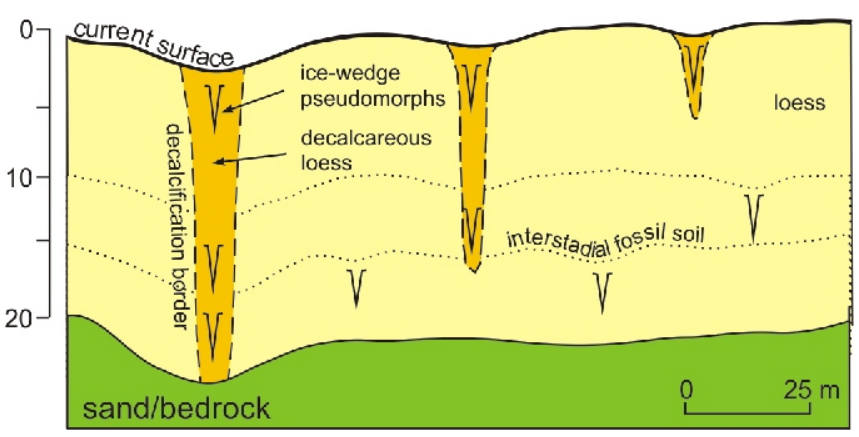

Fig. 13. The scheme of geologically controlled thermokarst CD development on the Nałęczów Plateau

Thermokarst CDs in areas with thin loess cover underlain by poorly permeable (A) and permeable (B) deposits and thic loess cover underlain by poorly permeable (C) and permeable (D) deposits 
tions (ice lenses) that depended, as was the case with ice wedges, on local geological conditions. Platy fabrics derived from ice lensing are common under the bottom of the CDs.

\section{CONCLUSIONS}

The loess lowlands in Poland experienced multiple phases of cold climate-induced periglaciation during the Pleistocene. Geological conditions, dependent on the type of deposits underlying the loess and their relief, shaped the drainage conditions and thus influenced the ice content in past permafrost, which, consequently, determined the development of thermokarst forms. The variation of geological conditions in the region studied was the most significant factor influencing the development of thermokarst CDs. Thermokarst processes had the strongest impact on areas with a thin loess cover (several metres thick), underlain by poorly permeable deposits (clays, clayey loams, glacial tills) with a small variation of relief. The highest concentrations of CDs on the regional scale $\left(30-40 \mathrm{CDs} / \mathrm{km}^{2}\right)$ are recorded in such areas. Conditions that were the least conducive to the development of thermokarst relief existed in areas where the loess lies on a permeable substrate (bedrock or sandy deposits) with significant relative heights. Such areas have low densities of CDs in comparison with the whole region (a few CDs $/ \mathrm{km}^{2}$ ).

The occurrence of primary depressions under the loess cover, particularly in the poorly permeable deposits (glacial tills with dead-ice topography), locally increased the water content in the loess cover and thus created long-lasting conditions con- ducive to the formation of local ice concentrations in the upper part of the permafrost. In such areas with unique geological and topographic conditions, junctions of polygonal networks could develop; they recurred during the stages of permafrost aggradation (at least twice in the Early (Lower) and Late (Upper) Plenivistulian) during the Last Glacial. At least two generations of polygonal networks of different ages may have been superimposed on one another in these areas, forming the basis for the development of at least two generations of superimposed thermokarst depressions of different ages. These forms are among the larger and deeper CDs occurring on the Nałęczów Plateau.

The results obtained indicate that forms of thermokarst origin can be the dominant type of CDs in the loess areas of the Nałęczów Plateau.

Acknowledgements. The research was financially supported by National Science Centre Grant 2012/07/B/ST10/04164, PB-B-12-287-00-13: The origin and evolution of closed depressions in the loess areas in the Lublin Upland and their importance for the reconstruction of postglacial morphogenesis of the loess cover. The authors wish to thank P. Demczuk and P. Bartmiński for carrying out the georadar surveys. We would like extend sincere thanks to the reviewers B. Van Vliet-Lanoë and P.I Bertran for their detailed and constructive comments, which significantly helped us to improve this paper. We kindly thank T. Solovey and an anonymous reviewer for their useful reviews. The editor-in-chief of the Geological Quarterly, T. Peryt, is acknowledged for helpful comments that contributed to the final version of the article.

\section{REFERENCES}

Andrieux, E., Bertran, P., Saito, K., 2015. Spatial analysis of the French Pleistocene permafrost by a GIS database. Permafrost and Periglacial Processes, 27: 17-30.

Bertran, P., Andrieux, E., Antoine, P., Coutard, S., Deschodt, L., Gardere, F., Hernandez, M., Legentil, C., Lenoble, A., Liard, M., Mercier, N., Moine, O., Sitzia, L., Van Vliet-Lanoë, B., 2013. Distribution and chronology of Pleistocene permafrost features in France: Database and first results. Boreas, 10: 1-13.

Black, R.F., 1969. Thaw depressions and thaw lakes. A review. Biuletyn Peryglacjalny, 19: 131-150.

Błaszkiewicz, M., 2011. Timing of the final disappearance of permafrost in the central European Lowland, as reconstructed from the evolution of lakes in N Poland. Geological Quarterly, 55 (4): 361-374.

Bogutsky, A.B., 1987. The main loess and paleosol horizons of periglacial Pleistocene loess-soil series in the south-western part of the Eastern European Platform (in Russian). In: Stratigraphy and Correlation of Marine and Continental Deposits in Ukraine (ed. E.F. Shniukov): 46-52. Naukova Dumka, Kiev.

Brown, J., Sellmann, P.V., 1973. Permafrost and coastal plain history of arctic Alaska. Arctic Institute of North America, Technical Paper, 25: 31-47.

Cegła, J., 1969. Influence a capillary ground moisture on eolian accumulation of loess. Bulletin de L'academie Polonaise des Sciences. Serie des Sciences Geologie et Geographie, 17: 25-27.

Czudek, T., Demek, J., 1970. Thermokarst in Siberia and its influence on the development of lowland relief. Quaternary Research, 1: 103-120.
De Groot, Th., Cleveringa, P., Klijnstra, B., 1987. Frost-mound scars and the evolution of a Late Dryas environment (northern Netherlands). Geologie en Mijnbouw, 66: 239-250.

Ewartowski, M., Kijowski, A., Szuman, I., Tomczyk, A., Kasprzak, L., 2016. Low-altitude remote sensing and GIS-based analysis of cropmarks: classification of past thermal-contraction-crack polygons in central western Poland. Geomorphology, http://dx.doi.org/10.1016/j.geomorph.2016.07.022

Farquharson, L.M., Mann, D.H., Grosse, G., Jones, B.M., Romanovsky, V.E., 2016. Spatial distribution of thermokarst terrain in Arctic Alaska. Geomorphology, 273: 116-133.

French, H.M., 2007. The Periglacial Environment. Wiley.

French, H., Shur, Y., 2010. The principles of cryostratigraphy Earth-Science Reviews, 101: 190-206.

Gardziel, Z., Harasimiuk, M., Jezierski, W., Pawłowski, A., Zgłobicki, W., 2006. Gully erosion in the western part of the Nałęczów Plateau (Lublin Upland) (in Polish with English summary). Przegląd Geologiczny, 54: 768-776.

Gawrysiak, L., Harasimiuk, M., 2012. Spatial diversity of gullies density on Lublin Upland and Roztocze Hills (SE Poland). Annales UMCS, B, 67: 27-43.

Goehring, L., 2013. Evolving fracture patterns: columnar joints, mud cracks and polygonal terrain. Philosophical Transactions of the Royal Society A. Mathematical, Physical and Engineering Sciences, 371: 20120353. http://dx.doi.org/10.1098/rsta.2012.0353

Goździk, J.S., 1995. A permafrost evolution and its impacts on some depositional conditions between 20 and $10 \mathrm{ka}$ in Poland. Biuletyn Peryglacjalny, 34: 53-72. 
Ghysels, G., Heyse, I., 2006. Composite-wedge pseudomorphs in Flanders, Belgium. Permafrost and Periglacial Processes, 17: $146-161$.

Guidelines for Soil Descriptions, 2006. Guidelines for Soil Descriptions (fourth ed). Food and Agriculture Organization of the United Nations (FAO), Rome.

Haesaerts, P., Van Vliet-Lanoë, B., 1981. Phénomènes périglaciaires et sols fossils observés à Maisières-Canal, a Harmignies et à Rocourt. Biuletyn Peryglacjalny, 28: 291-325.

Harasimiuk, M., 1980. Rzeźba strukturalna Wyżyny Lubelskiej i Roztocza (in Polish). UMCS, Lublin.

Harasimiuk, M., 1987. Lithologic properties as indices of the sedimentation conditions of the Vistulian loesses in the eastern part of the Nałęczów Plateau (SE Poland). Annales UMCS, B, 41: 179-202.

Harasimiuk, M., Henkiel, A., 1976. Peculiarities of the loess cover in the western part of the Nałęczów Plateau (in Polish with English summary). Biuletyn Instytutu Geologicznego, 297: 177-181.

Harasimiuk, M., Henkiel, A., 1978. The influence of the geological structure and of the substratum relief on the configuration of loess cover in the area of the western part of the Nałeczów Plateau (in Polish with English summary). Annales UMCS, B 30/31: 55-80

Harasimiuk, M., Henkiel, A., 1981. Szczegółowa Mapa Geologiczna Polski 1:50 000, arkusz Lublin (in Polish). Państwowy Instytut Geologiczyny, Warszawa.

Harasimiuk, M., Jezierski, W., 2001. Profil lessów w Skowieszynie na Wyżynie Lubelskiej (in Polish). Podstawowe profile lessów w Polsce, 2: 93-100.

Harry, D.G., French, H.M., 1983. The orientation and evolution of thaw lakes, southwest Banks Island, Canadian Arctic. In: Proceedings of the 4th International Conference on Permafrost 456-461. National Academy Press, Washington, D.C.

Harry D.G., Goździk, J., 1988. Ice wedges: growth, thaw transformations and palaeoenvironmental significance. Journal of Quaternary Science, 3: 39-55.

Helmens, K.F., 2014. The Last Interglacial-Glacial cycle (MIS 5-2) re-examined based on long proxy records from central and northern Europe. Quaternary Science Reviews, 86: 115-143.

Henkiel, A., Nitychoruk, J., 1980. Joints and mesoscopic structures in the Cretaceous and Palaeocene rocks in the North-Western part of the Lublin Upland. Annales UMCS, sec. B, 35/36: 13-27.

Henriksen, M., Mangerud, J., Matiouchkov, A., Murray, A.S. Paus, A., Svendsen, J.I., 2008. Intriguing climatic shifts in a 90 kyr old lake record from northern Russia. Boreas, 37: 20-37.

Huijzer, A.S., Isarin, R.F.B., 1997. The reconstruction of past climates using multiproxy evidence: an example of the Weichselian Pleniglacial in north-west and central Europe. Quaternary Science Reviews, 16: 513-533.

Huijzer, B., Vandenberghe, J., 1998. Climatic reconstruction of the Weichselian Pleniglacial in northwestern and central Europe. Journal of Quaternary Science, 13: 391-417.

Isarin, R.F.B., 1997. Permafrost distribution and temperatures in Europe during the Younger Dryas. Permafrost and Periglacial Processes, 8: 313-333.

Isarin, R.F.B., Renssen, H., 1999. Reconstructing and modelling Late Weichselian climates: the Younger Dryas in Europe as a case study. Earth-Science Reviews, 48: 1-38.

Jahn, A., 1975. Problems of the Periglacial Zone. PWN, Warszawa.

Jary, Z., 1996. Chronostratigraphy and the course of loess sedimentation in SW Poland on the example of the Głubczyce Upland and Trzebnica Hills, Acta Universitatis Wratislaviensis 1766, Studia Geograficzne, 63.

Jary, Z., 2009. Periglacial markers within the Late Pleistocene loess-palaeosol sequences in Poland and Western Ukraine. Quaternary International, 198: 124-135.

Jary, Z., Ciszek, D., 2013. Late Pleistocene loess-palaeosol sequences in Poland and western Ukraine. Quaternary International, 296: 37-50.

Kanevskiy, M., Shur, Y., Jorgenson, M.T., Ping, C.L., Michaelson, G.J., Fortier, D., Stephani, E., Dillon, M., Tumskoy, V., 2013.
Ground ice in the upper permafrost of the Beaufort Sea coast of Alaska. Cold Regions Science and Technology, 85: 56-70.

Kanevskiy, M., Shur, Y., Krzewinski, T., Dillon, M., 2013. Structure and properties of ice-rich permafrost near Anchorage, Alaska. Cold Regions Science and Technology, 93: 1-11.

Kasse, C., Vandenberghe, J., 1998. Topographic and drainage control on Weichselian ice-wedge and sand-wedge formation, Vennebrügge, German-Dutch Border. Permafrost and Periglacial Processes, 9: 95-106.

Kasse, C., Huijzer, A.S., Krzyszkowski, D., Bohncke, S.J.P., Coope, G.R., 1998. Weichselian Late Pleniglacial and Late-glacial depositional environments, Coleoptera and periglacial climatic records from central Poland (Bełchatów). Journal of Quaternary Science, 13: 455-469

Kasse, C., Vandenberghe, J., Huissteden, J., van Bohncke, S.J.P., Bos, J.A.A., 2003. Sensitivity of Weichselian fluvial systems to climate change (Nochten mine, eastern Germany). Quaternary Science Reviews, 22: 2141-2156.

Kołodyńska-Gawrysiak, R., Chabudziński, Ł., 2012. Morphometrical features and distribution of closed depressions on the Nałęczów Plateau (Lublin Upland, SE Poland). Annales UMCS, B, 67: 45-61.

Kołodyńska-Gawrysiak, R., Poesen, J., 2017. Closed depressions in the European loess belt - natural or anthropogenic origin? Geomorphology, 288: 111-128.

Kołodyńska-Gawrysiak, R., Harasimiuk, M., Chabudziński, Ł., Jezierski, W., Telecka, M., 2015. Geological conditions of the distribution of closed depressions in the Nałęczów Plateau (Lublin Upland, E Poland): are they an origin determinant? Landform Analysis, 29: 9-18.

Kołodyńska-Gawrysiak, R., Chodorowski, J., Mroczek, P., Plak, A., Kiebała, A., Zgłobicki, W., Trzciński, J., Standzikowski, K., 2017. The impact of natural and anthropogenic processes on the evolution of closed depressions in loess areas. A multi-proxy case study from Nałęczów Plateau, Eastern Poland. Catena, 149: 1-18.

Konrad, J.M., Morgenstern, N.R., 1980. A mechanistic theory of ice lens formation in fine-grained soils. Canadian Geotechnical Journal, 17: 473-486.

Kozarski, S., 1995. The periglacial impact on the deglaciation area of northern Poland after 20 kyr BP. Biuletyn Peryglacjalny, 34: 73-102.

Kühl, N., Litt, T., Schölzel, Ch., Hense, A., 2007. Eemian and Early Weichselian temperature and precipitation variability in northern Germany. Quaternary Science Reviews, 26: 3311-3317.

Lachenbruch, A.H., 1966. Contraction theory of ice-wedge polygons: a qualitative discussion. National Academy of SciencesNational Research Council, Washington, publication no, 1287: 63-71

Mackay, J.R., 1966. Segregated epigenetic ice and slumps in permafrost, Mackenzie Delta Area. Geographical Bulletin, 8: 59-80.

Mackay, J.R., 1974. The rapidity of tundra polygon growth and destruction, Tuktoyartuk Peninsula, Richards Island Area. N.W.T. Geological Survey of Canada, Paper, 74-1: 391-392.

Mackay, J.R., 1990. Some observations on the growth and deformation of epigenetic, syngenetic and anti-syngenetic ice wedges. Permafrost and Periglacial Processes, 1: 15-29.

Marks, L., Gałązka, D., Woronko, B., 2016. Climate, environment and stratigraphy of the last Pleistocene glacial stage in Poland. Quaternary International, 420: 259-271.

Maruszczak, H., 1964. Mapa geomorfologiczna województwa lubelskiego 1: 300000 (in Polish). Zakład Geoekologii i Paleogeografii UMCS, Lublin.

Maruszczak, H., 1973. Erozja wąwozowa we wschodniej części pasa wyżyn południowopolskich (in Polish). Zeszyty Problemowe Postępu Nauk Rolniczych, 151: 15-30.

Maruszczak, H., 1976. Loess stratigraphy of south-eastern Poland (in Polish with English summary). Biuletyn Instytutu Geologicznego, 297: 135-175.

Maruszczak, H., 1980. Stratigraphy and chronology of the vistulian loess in Poland. Quaternary Studies in Poland, 2: 57-76. 
Maruszczak, H., 1991. Stratigraphical differentation of Polish loesses. Main Sections of Loesses in Poland: 13-35.

Maruszczak, H., 2001. Schemat stratygrafii lessów i gleb śródlessowych w Polsce (in Polish). Podstawowe profile lessów w Polsce, 2: 17-29.

Michalczyk, Z., 1986. Warunki występowania i krążenia wód na obszarze Wyżyny Lubelskiej i Roztocza (in Polish). UMCS, Lublin.

Morgenstern, A., Ulrich, M., Gunther, F., Roessler, S., Fedoreva, I. V., Rudaya, N.A., Wetterich, S., Boike, J., Scirrmeister, L., 2013. Evolution of thermokarst in East Siberian ice-rich permafrost: a case study. Geomorphology, 201: 363-379.

Murton, J.B., 1996. Thermokarst-lake-basin sediments, Tuktoyaktuk Coastlands, Western Arctic Canada Sedimentology, 43: 737-760.

Murton, J.B., Worsley, P., Goździk, J., 2000. Sand veins and wedges in cold aeolian environments. Quaternary Science Reviews, 19: 899-922.

Murton, J.B., Goslar, T., Edwards, M.E., Bateman, M.D., Danilov, P.P., Savvinov, G.N., Gubin, S.V., Ghaleb, B., Haile, J., Kanevskiy, M., Lozhkin, A.V., Lupachev, A.V., Murton, D.K., Shur, Y., Tikhonov, A., Vasilchuk, A.C., Vasilchuk, Y.K., Wolfe, S.A., 2015. Palaeoenvironmental interpretation of Yedoma Silt (Ice Complex) deposition as cold-climate loess, Duvanny Yar, Northeast Siberia. Permafrost and Periglacial Processes, 26: 208-288

Nowacka, M., 1992. Kazimierski Park Krajobrazowy (in Polish). System obszarów chronionych województwa lubelskiego: 61-93.

Paus, A., 1995. The Late Weichselian and early Holocene history of tree birch in south Norway and the Bölling Betula time-lag in northwest Europe. Review of Palaeobotany and Palynology, 85: 243-262.

Penner, E., Goodrich, L.E., 1981. Location of segregated ice in frost susceptible soil. Engineering Geology, 18: 231-244.

Pissart, A., 1985. Pingo and palsas: a review of the present state of knowledge. Polar Geography. 9: 171-195.

Pissart, A., 2010. Remnants of lithalsas on the Hautes Fagnes plateau (Belgium) are on weathered quartzitic rocks. Zeitschrift für Geomorphologie, 54: 1-15.

Pollard, W., French, H.M., 1980. A first approximation of the volume of ground ice, Richards Island, Pleistocene Mackenzie delta, Northwest Territories, Canada. Canadian Geotechnical Journal, 17: 509-516.

Pożaryska, K., 1967. Cretaceous-Tertiary transition beds in Poland (except for the Carpathians) (in Polish with English summary). Geological Quarterly, 11 (3): 661-672.

Pożaryski, W., Maruszczak, H., Lindner, L., 1994. Chronostratigraphy of Pleistocene deposits and evolution of the Middle Vistula River Valley with particular attention to the gap through the South Polish Uplands (in Polish with English summary). Prace Państwowego Instytutu Geologicznego, 147: 1-58.

Seppälä, M., 1997. Piping causing thermokarst in permafrost, Ungava Peninsula, Quebec, Canada. Geomorphology, 20: 313-319.

Shur, Y.L., 1988. The upper horizon of permafrost soils. Proceedings of the Fifth International Conference on Permafrost, 1 : 867-871.

Shur, Y.L., Jorgenson M.T., 2007. Patterns of permafrost formation and degradation in relation to climate and ecosystems. Permafrost and Periglacial Processes, 18: 7-19.

Soloviev, P.A., 1973. Thermokarst phenomena and landforms due to frost heaving in Central Yakutia. Biuletyn Peryglacjalny, 23: 135-155.

Sparks, B.W., Williams, R.B.G., Bell, F.G., 1972. Presumed ground-ice depressions in East Anglia. Proceedings of the Royal Society of London, A327: 329-343.

Stankowski, W., 2012. Transformation from natural (thermal contraction) to anthropogenic (resource exploitation) depressions in the Krotoszyn-Koźmin-Raszków area (Polish Lowland). Geologos, 18: 43-50.

Starkel, L., 1988. Paleogeography of the periglacial zone in Poland during the maximum advance of the Vistulian ice sheet. Geographia Polonica, 55: 151-163.

Svensson, H., 1982. The use of aerial photographs and remote sensing techniques in research on fossil periglacial features. Biuletyn Peryglacjalny, 29: 129-138.

Śnieszko, Z., 1995. Evolution of the loess areas of the Polish Uplands during last 15000 years (in Polish with English summary). Prace Naukowe Uniwersytetu Śląskiego, 1496: 1-124.

Toniolo, H., Kodial, P., Hinzman, L.D., Yoshikawa, K., 2009 Spatio-temporal evolution of a thermokarst in Interior Alaska. Cold Regions Science and Technology, 56: 39-49.

Ulrich, M., Wetterich, S., Rudaya, N., Frolova, L., Schmidt, J., Siegert, Ch., Fedorov, A.N., Zielhofer, Ch., 2017. Rapid thermokarst evolution during the mid-Holocene in Central Yakutia, Russia. The Holocene, doi: 10.1177/0959683617708454.

Vandenberghe, J., 1985. Paleoenvironment and stratigraphy during the Last Glacial in the Belgian-Dutch border region. Quaternary Research, 24: 23-38.

Vandenberghe, P., Pissart, A., 1993. Permafrost changes in Europe during the Last Glacial. Permafrost and Periglacial Processes, 4: 121-135.

Vandenberghe, J., Bohncke, S., Lammers, W., Zilverberg, L., 1987. Geomorphology and palaeoecology of the Mark valley (southern Netherlands): geomorphological valley development during the Weichselian and Holocene. Boreas, 16: 55-67.

Vandenberghe, J., French, H.M., Gorbunov, A., Marchenko, S. Velichko, A.A., Jin, H., Cui, Z., Zhang, T., Xudong, Wan, X., 2014. The Last Permafrost Maximum (LPM) map of the Northern Hemisphere: permafrost extent and mean annual air temperatures, 25-17 ka BP. Boreas, 43: 652-666.

Van Vliet-Lanoë, B., 1989. Dynamics and extent of the Weichselian permafrost in Western Europe (substage 5E to stage 1). Quaternary International, 3/4: 109-113.

Van Vliet-Lanoë, B., 1991. Chronostratigraphy and paleoclimatic meaning of cryogenic deformations in the Central European loess. GeoJournal, 24: 157-163.

Van Vliet-Lanoë, B., 1998. Frost and soils: implications for paleosols, paleoclimates and stratigraphy. Catena, 34: 157-183.

Van Vliet-Lanoë, B., 2005. Deformations in the Active Layer related with Ice/Soil Wedge Growth and Decay in Present Day Arctic. Paleoclimatic Implications. Annales de la Société Géologique du Nord, 12: 77-91.

Van Vliet-Lanoë, B., Hallegouët, B., 2001. European permafrost at the LGM and at its maximal extent. The Geological approach. In: Permafrost Response on Economic Development, Environmental Security and Natural Resources (eds. R. Paepe, V.P. Melnikov and V.D. Gorokhov), NATO Science Series (Series 2 Environment Security), 76: 195-213.

Van Vliet-Lanoë, B., Langohr, R., 1981. Correlation between fragipan and permafrost with special reference to Weichsel silty deposits in Belgium and Northern France. Catena, $8: 137-154$.

Van Vliet-Lanoë, B., Brulhet, J., Combes, P., Duvail, C., Ego, F., Baize, S., Cojan, I. 2017. Quaternary thermokarst and thermal erosion features in northern France: origin and palaeoenvironments. Boreas, 46: 442-461.

Velichko, A.A., 1990. Loess-paleosol formation on the Russian Plain. Quaternary International, 7/8: 103-114.

Velichko, A.A., Bogucki, A.B., Morozowa, T.D., Udartsev, V.P., Khalcheva, T.A., Tsatskin, A.I., 1984. Periglacial Landscapes of the East European Plain. Late Quaternary Environments of the Soviet Union: 95-118.

Washburn, A.L., 1979. Geocryology. A survey of periglacial processes and environment. Arnold Publ., London.

Yershov, E.D., 1998. General Geocryology. Studies in Polar Research. Cambridge University Press. 